Prepared in cooperation with the City of Kansas City, Missouri

\title{
Flood-Inundation Maps and Wetland Restoration Suitability Index for the Blue River and Selected Tributaries, Kansas City, Missouri, and Vicinity, 2012
}

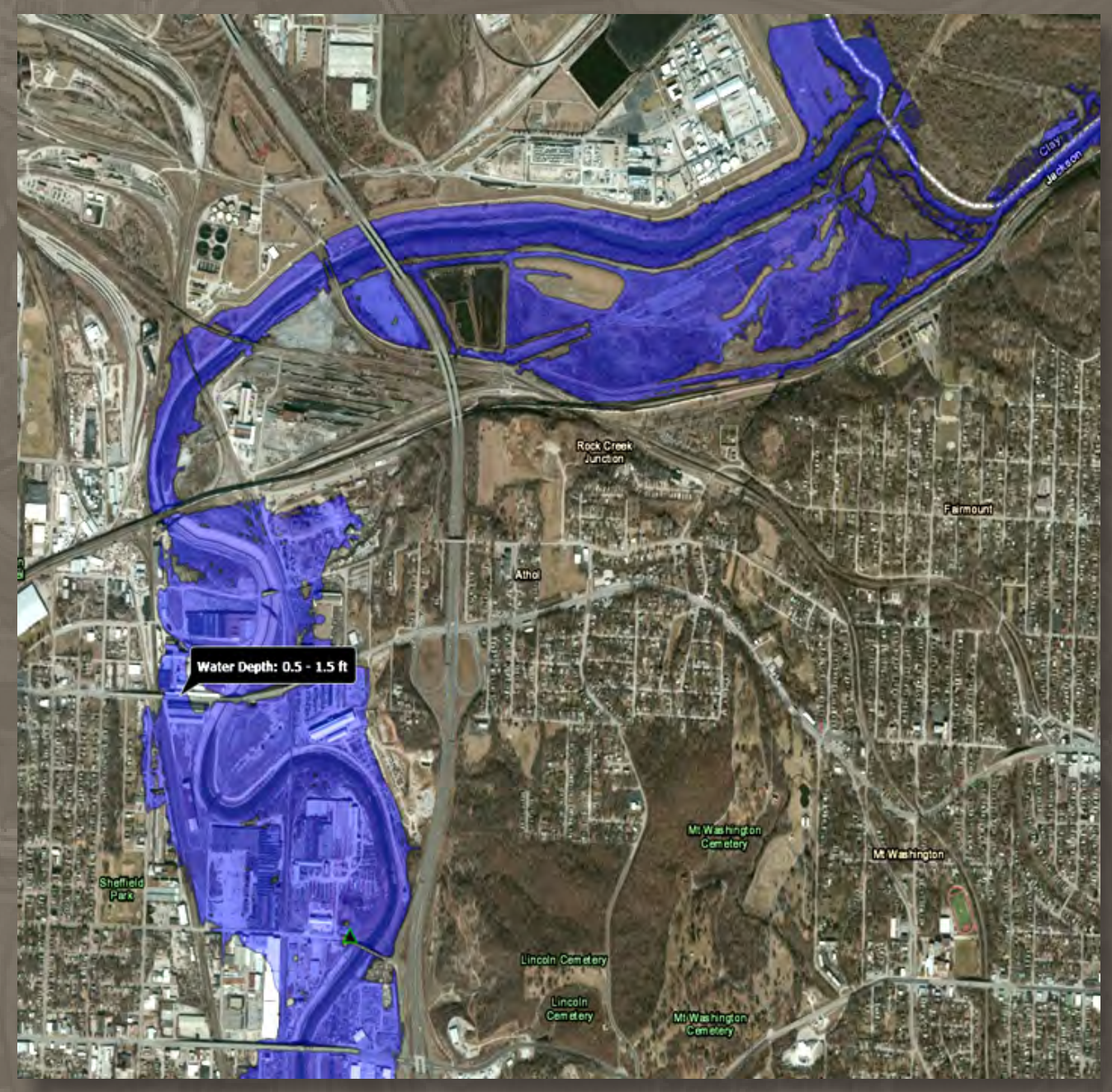

Scientific Investigations Report 2014-5180

Version 1.1, April 2015

U.S. Department of the Interior

U.S. Geological Survey 
Cover. Map shows the extent of flood inundation on the lower Blue River in Kansas City, Missouri, for a stage of 41.0 feet at the U.S Geological Survey Blue River at 12th Street reference gage (from U.S. Geological Survey Flood-Inundation Mapper Web site, September 2014, http:/water.usgs.gov/osw/flood_inundation/). 


\section{Flood-Inundation Maps and Wetland Restoration Suitability Index for the Blue River and Selected Tributaries, Kansas City, Missouri, and Vicinity, 2012}

By David C. Heimann, Trina E. Weilert, Brian P. Kelly, and Seth E. Studley

Prepared in cooperation with the City of Kansas City, Missouri

Scientific Investigations Report 2014-5180

Version 1.1, April 2015 


\title{
U.S. Department of the Interior SALLY JEWELL, Secretary
}

\section{U.S. Geological Survey Suzette M. Kimball, Acting Director}

\author{
U.S. Geological Survey, Reston, Virginia: 2014 \\ First release: 2015 \\ Revised: April 2015 (ver. 1.1)
}

\begin{abstract}
For more information on the USGS - the Federal source for science about the Earth, its natural and living resources, natural hazards, and the environment, visit http://www.usgs.gov or call 1-888-ASK-USGS.

For an overview of USGS information products, including maps, imagery, and publications, visit http://www.usgs.gov/pubprod

To order this and other USGS information products, visit http://store.usgs.gov
\end{abstract}

Any use of trade, firm, or product names is for descriptive purposes only and does not imply endorsement by the U.S. Government.

Although this information product, for the most part, is in the public domain, it also may contain copyrighted materials as noted in the text. Permission to reproduce copyrighted items must be secured from the copyright owner.

Suggested citation:

Heimann, D.C., Weilert, T.E., Kelly, B.P., and Studley, S.E., 2014, Flood-inundation maps and Wetland Restoration Suitability Index for the Blue River and selected tributaries, Kansas City, Missouri, and vicinity, 2012 (ver. 1.1, April 2015): U.S. Geological Survey Scientific Investigations Report 2014-5180, 23 p., http://dx.doi.org/10.313/ sir20145180.

ISSN 2328-0328 (online) 


\section{Acknowledgments}

The authors wish to thank the local and Federal agencies that have cooperated in the funding for the operation and maintenance of the streamgages used for this study, especially the City of Kansas City, Missouri, and the U.S. Army Corps of Engineers. Special thanks are given to the City of Kansas City, Water Services Department, for their cooperation in this study and to the National Weather Service for their continued support to the U.S. Geological Survey flood-inundation mapping initiative.

\section{Contents}

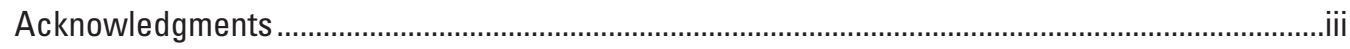

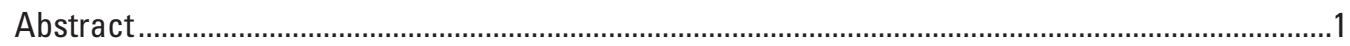

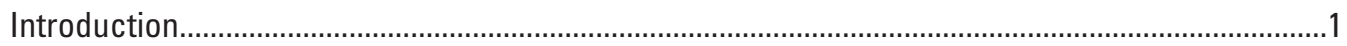

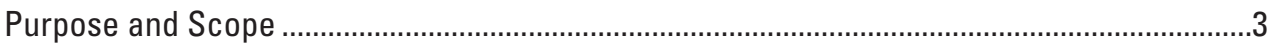

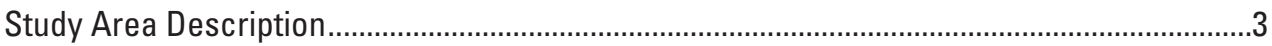

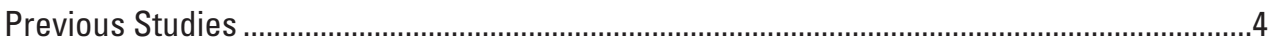

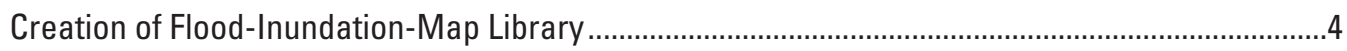

Computation of Water-Surface Profiles..............................................................................

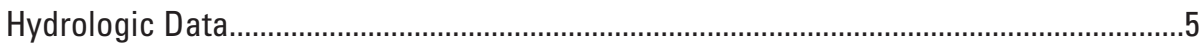

Topographic and Bathymetric Data .............................................................................

Hydraulic Structures .....................................................................................................

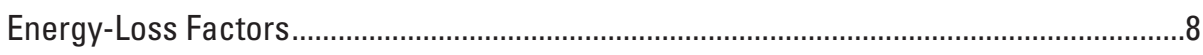

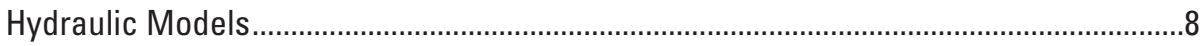

Development of Water-Surface Profiles........................................................................

Development of Stream-Velocity Maps ....................................................................

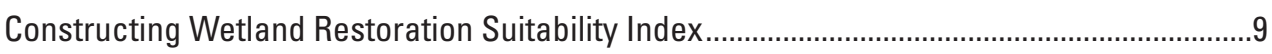

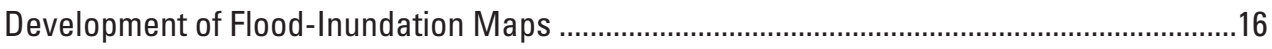

Flood-Inundation Map Delivery ..................................................................................17

Stream-Velocity Maps ..................................................................................................17

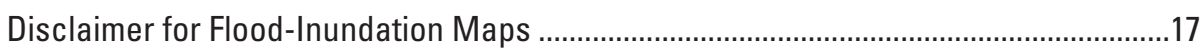

Uncertainties and Limitations Regarding Use of Flood-Inundation Maps .......................17

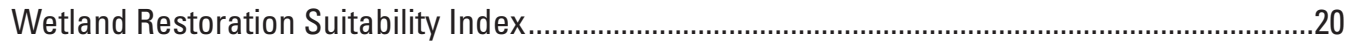

Summary

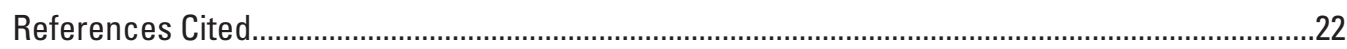

\section{Figures}

1. Blue River Basin, streamgage locations, and extents for flood-inundation maps,

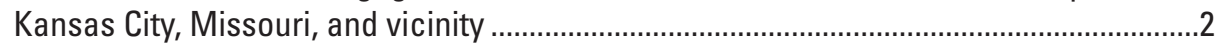

2. Two-dimensional model reaches of the Blue River, Kansas City, Missouri........................6 
3. Basin slope data layer used in the development of the Blue River Wetland Restoration Suitability Index, Kansas City, Missouri, and vicinity.

4. Flow-accumulation data layer used in the development of the Blue River Wetland Restoration Suitability Index, Kansas City, Missouri, and vicinity.

5. Flood-frequency data layer used in the development of the Blue River Wetland Restoration Suitability Index, Kansas City, Missouri, and vicinity.

6. Land-cover data layer used in the development of the Blue River Wetland Restoration Suitability Index, Kansas City, Missouri, and vicinity.

7. Stream buffer data layer used in the development of the Blue River Wetland Restoration Suitability Index, Kansas City, Missouri, and vicinity. 14

8. Hydric soils data layer used in the development of the Blue River Wetland Restoration Suitability Index, Kansas City, Missouri, and vicinity.

9. Linear regression model used to compute Missouri River water-surface elevation at the mouth of the Blue River based on stages at the Missouri River at Kansas City, Missouri. (Source of simulated data used in analysis is U.S. Army Corps of Engineers, 2004)

10. Distribution of Blue River water velocity in the downstream reach modeled using a two-dimensional model for low, moderate, and high flows, Kansas City, Missouri........18

11. Distribution of Blue River water velocity in the upstream reach modeled using a two-dimensional model for low, moderate, and high flows, Kansas City, Missouri........19

12. Wetland Restoration Suitability Index map for the riparian areas of the Blue River and selected tributaries, Kansas City, Missouri, and vicinity...

\section{Tables}

1. Streamgage information for the Blue River study basin, Kansas City, Missouri, and vicinity. ... link

2. Impervious area and 50-, 20-, 10-, 1-, and 0.2-percent annual exceedance probability peak-streamflow estimates for streamgages on the Blue River and selected tributaries, Kansas City, Missouri, and vicinity

3. Simulated river reaches and corresponding reference streamgages used to develop flood-inundation maps for the Blue River, Brush Creek, and Indian Creek in Kansas City, Missouri, and vicinity...

4. U.S. Geological Survey streamgages and ratings used to provide streamflow and confirm water-surface elevations in the hydraulic models for the Blue River, Brush Creek, and Indian Creek, Kansas City, Missouri, and vicinity.

5. National Weather Service flood categories, stages, observed and simulated water-surface elevations, and corresponding streamflows for simulated water-surface profiles at reference streamgages on the Blue River and selected tributaries, Kansas City, Missouri, and vicinity.

6. Summary of hydraulic structures included in HEC-RAS models for the Blue River, Brush Creek, and Indian Creek, Kansas City, Missouri, and vicinity.

7. Comparison of measured and simulated water-surface elevations of the two-dimensional models at selected locations along the Blue River for the flood of June 14, 2010, Kansas City, Missouri

8. Feature layers, weights, categories, and scale values, used in the development of a Wetland Restoration Suitability Index for the Blue River and selected tributaries, Kansas City, Missouri, and vicinity 


\section{Flood-Inundation Maps}

Maps and additional materials are available for viewing and Print on Demand online through the U.S. Geological Survey Flood-Inundation Mapping Program page at http://water.usgs.gov/osw/ flood_inundation/and following the provided link to the Flood Inundation Mapper Web site. Once the reader reaches the current version of the Flood-Inundation Mapper Web site, specific links to a streamgage and reach of interest can be established using the streamgage information provided in Table 1. Established links can be bookmarked by the user for more efficient access in the future and updated as necessary as the Flood-Inundation Mapper undergoes possible revisions. 


\section{Conversion Factors and Datums}

Inch/Pound to SI

\begin{tabular}{lcl}
\hline \multicolumn{1}{c}{ Multiply } & By & \multicolumn{1}{c}{ To obtain } \\
\hline foot $(\mathrm{ft})$ & Length & meter $(\mathrm{m})$ \\
mile $(\mathrm{mi})$ & 0.3048 & kilometer $(\mathrm{km})$ \\
\hline \multicolumn{3}{c}{ Area } \\
\hline square $\mathrm{mile}\left(\mathrm{mi}^{2}\right)$ & 1.609 & square kilometer $\left(\mathrm{km}^{2}\right)$ \\
\hline & 2.590 & \\
\hline cubic foot per second $(\mathrm{ft} / \mathrm{s})$ & Flow rate & cubic meter per second $\left(\mathrm{m}^{3} / \mathrm{s}\right)$ \\
foot per second $(\mathrm{ft} / \mathrm{s})$ & 0.02832 & meter per second $(\mathrm{m} / \mathrm{s})$ \\
\hline & 0.3048 & \\
\hline foot per mile $(\mathrm{ft} / \mathrm{mi})$ & Hydraulic gradient & meter per kilometer $(\mathrm{m} / \mathrm{km})$ \\
\hline
\end{tabular}

Vertical coordinate information is referenced to (1) stage, the height above an arbitrary datum established at a streamgage, and (2) elevation, the height above the North American Vertical Datum of 1988 (NAVD 88).

Horizontal coordinate information is referenced to the North American Datum of 1983 (NAD 83).

Water year is defined as the 12-month period from October 1 through September 30 of the following year. 


\section{Abbreviations}

\begin{tabular}{|c|c|}
\hline AEP & annual-exceedance probability \\
\hline AHPS & $\begin{array}{l}\text { National Weather Service Advanced Hydrologic Prediction Service } \\
\text { (http:/water.weather.gov/ahps/) }\end{array}$ \\
\hline ALERT & $\begin{array}{l}\text { Automated Local Elevation in Real Time and in this study refers to } \\
\text { streamgages operated by the City of Kansas City }\end{array}$ \\
\hline DGPS & differential global position system \\
\hline HEC-GeoRAS & 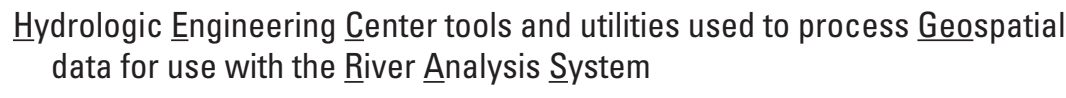 \\
\hline HEC-RAS & $\begin{array}{l}\text { Hydrologic Engineering Center river analysis system developed by the U.S. } \\
\text { Army Corps of Engineers for hydraulic modeling of rivers }\end{array}$ \\
\hline FESWMS & $\begin{array}{l}\text { Federal Highway Administration finite element surface-water modeling } \\
\text { system. }\end{array}$ \\
\hline FIRM & flood insurance rate map \\
\hline FST2DH & two-dimensional depth-averaged flow and sediment transport model \\
\hline GIS & geographic information system \\
\hline lidar & light detection and ranging data \\
\hline NHD & National Hydrography Dataset \\
\hline NLCD & National Land Cover Database \\
\hline NWI & National Wetlands Inventory \\
\hline RMSE & root mean square error \\
\hline RMSEz & root mean square error of elevation data \\
\hline SSURGO & Soil Survey Geographic database \\
\hline WPST & Wetland Potential Screening Tool \\
\hline WRSI & Wetland Restoration Suitability Index \\
\hline
\end{tabular}





\title{
Flood-Inundation Maps and Wetland Restoration Suitability Index for the Blue River and Selected Tributaries, Kansas City, Missouri, and Vicinity, 2012
}

\author{
By David C. Heimann, ${ }^{1}$ Trina E. Weilert, ${ }^{2}$ Brian P. Kelly, ${ }^{1}$ and Seth E. Studley ${ }^{1 /}$
}

\section{Abstract}

Digital flood-inundation maps for a 39.7-mile reach of the Blue River and selected tributaries (Brush Creek, Indian Creek, and Dyke Branch) at Kansas City, Missouri, and vicinity, were created by the U.S. Geological Survey (USGS) in cooperation with the City of Kansas City, Missouri. The flood-inundation maps, accessed through the USGS FloodInundation Mapping Science Web site at http://water.usgs. gov/osw/flood_inundation/, depict estimates of the spatial extent and depth of flooding corresponding to selected water levels (stages) at 15 reference streamgages and associated stream reaches in the Blue River Basin. Near-real-time stage data from the streamgages may be obtained from the USGS National Water Information System at http://waterdata. usgs.gov/ or the National Weather Service (NWS) Advanced Hydrologic Prediction Service (AHPS) at http://water.weather. gov/ahps/, which also forecasts flood hydrographs at selected sites.

Flood profiles were computed for each of 15 reaches by means of one-dimensional or two-dimensional hydraulic models. The models were calibrated by using the current stage-streamflow relations at 10 USGS streamgages and documented highwater marks from the flood of June 14, 2010. Hydraulic models were then used to compute water-surface profiles for flood stages at 1-foot intervals referenced to the streamgage datum and ranging from the National Weather Service Action stage, or near bankfull streamflow, through the stage corresponding to, or exceeding, the estimated 0.2-percent annual exceedance probability flood (500-year recurrence interval flood).

The simulated water-surface profiles were then combined with a geographic information system (GIS) terrain model (derived from light detection and ranging (lidar) data having a vertical accuracy of less than 0.6 foot and maximum nominal horizontal post spacing of 2.46-3.28 feet) to delineate the area flooded at each 1 -foot increment of stage. The availability of these flood-inundation maps, along with Internet information regarding current stage from the USGS streamgages and

\footnotetext{
${ }^{1}$ U.S. Geological Survey
}

${ }^{2}$ Currently U.S. Department of Agriculture, formerly U.S. Geological Survey forecasted high-flow stages from the NWS, will provide emergency management personnel and residents with information that is critical for flood response activities such as evacuations and road closures, as well as for postflood recovery efforts.

Additional information in this report includes maps of simulated stream velocity for an 8.2 mile, two-dimensional modeled reach of the Blue River and a Wetland Restoration Suitability Index (WRSI) generated for the study area that was based on hydrologic, topographic, and land-use digital feature layers. The calculated WRSI for the selected flood-plain area ranged from 1 (least suitable for possible wetland mitigation efforts) to 10 (most suitable for possible wetland mitigation efforts). A WRSI of 5 to 10 is most closely associated with existing riparian wetlands in the study area. The WRSI allows for the identification of lands along the Blue River and selected tributaries that are most suitable for restoration or creation of wetlands. Alternatively, the index can be used to identify and avoid disturbances to areas with the highest potential to support healthy sustainable riparian wetlands.

\section{Introduction}

The City of Kansas City, Missouri, has an estimated population of about 460,000 (U.S. Census Bureau, 2010). Kansas City has experienced severe flooding many times, most notably in 1951, 1961, 1977, 1984, 1990, 1998, and 2010 (National Oceanic and Atmospheric Administration, National Weather Service, 2014b). During the past 30 years these floods resulted in damages within Kansas City costing tens of millions of dollars and more than 25 casualties (U.S. Army Corps of Engineers, 1967; Hauth and Carswell, 1981; Brush Creek Coordinating Committee, 2013). Most of the flood damages have been along the Blue River and several tributaries (Brush Creek, Indian Creek, Dyke Branch), all of which flow through the city (fig. 1). Flood plains within Kansas City are moderately to highly developed and contain a mix of residential and commercial structures.

Flood-inundation maps were generated for the downstream (Kelly and Rydlund, 2006) and upstream (Kelly and Huizinga, 2008) sections of the Blue River and for selected tributaries in previous studies. Emergency responders relied 


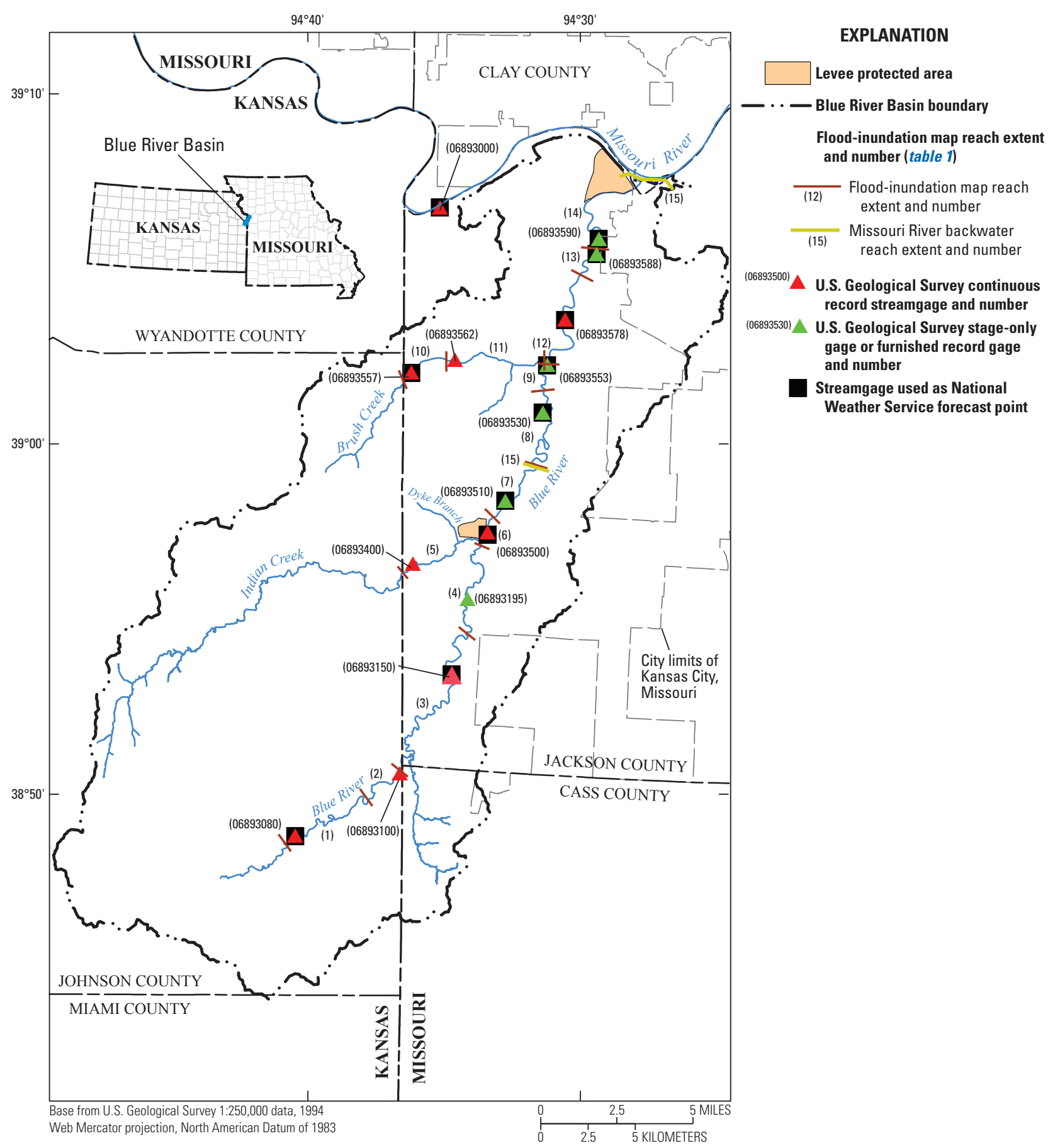

Figure 1. Blue River Basin, streamgage locations, and extents for flood-inundation maps, Kansas City, Missouri, and vicinity. 
on these flood-inundation maps and other information sources to make decisions on how to best alert the public and mitigate flood damages. A second source of information is U.S. Geological (USGS) streamgage data (available at $h t t p: / /$ mo.water.usgs.gov/) and Kansas City Automated Local Elevation in Real Time (ALERT) streamgage information (available at $h t t p: / / w w w . s t o r m w a t c h . c o m /)$ from which current (2014) or historical water levels (stages) and streamflows, if measured, can be obtained. A third source is the National Weather Service's (NWS) forecast of peak stages at selected reference streamgages through the Advanced Hydrologic Prediction Service (AHPS) Web site (http://water.weather.gov/ahps/).

Although the current stage (stage data which are updated every 15 minutes) at a USGS or ALERT streamgage is particularly useful near the streamgage, it is of limited use farther upstream or downstream from the streamgage because the water-surface elevation is not constant along the entire stream reach. Knowledge of a water level at a streamgage is difficult to translate into depth and areal extent of flooding at points distant from the gage. One way to address these informational gaps is to produce a library of flood-inundation maps that are referenced to the stages recorded at a streamgage. By referring to the appropriate map, emergency responders can discern the severity of flooding (depth of water and areal extent), identify roads that are or will soon be flooded, and make plans for notification or evacuation of residents in harm's way for some distance upstream and downstream from the streamgage. In addition, if residents have a better understanding of the potential extent of flooding it will likely motivate residents to take precautions and heed warnings that they previously might have disregarded. In 2012, the USGS, in cooperation with the City of Kansas City, began a project to produce a library of flood-inundation maps for 15 reaches of the Blue River and selected tributaries at Kansas City, Missouri, and nearby areas.

Wetlands historically have been an important component of the Missouri landscape, covering about 4.8 million acres, or nearly 11 percent, of the State in the 1780s (Dahl, 1990). About 87 percent of the wetlands in Missouri were drained and filled by the 1980s. Because of extensive land-cover and hydrological changes in urban areas, the degradation and losses of existing wetlands in such areas can be particularly severe. Urban wetlands, although subjected to many disturbances, still provide many functions that make their restoration important. These functions include provision of habitat for fish and wildlife species; water-quality protection; and recreational, educational, and aesthetic values (Ehrenfeld, 2004), which are particularly important given that generally little natural habitat is available in cities. Particular problems for restoration of wetlands in urban areas include ongoing disturbances, choosing between wetland creation and restoration, and determining the placement of wetland restoration or creation projects; however, given the extensive environmental alterations, remaining suitable areas for restoration are limited. A Wetland Restoration Suitability Index (WRSI) provides city planners, engineers, and developers with a geographic information system (GIS)based map to identify areas along the Blue River and selected tributaries with the highest potential of supporting healthy, sustainable riparian wetlands. Similar to the Wetland Potential Suitability Tool (WPST; Weller, 2008) on which the WRSI is based, the summary WRSI map is not meant to locate existing wetlands, but rather to identify land along the Blue River and selected tributaries that is the most suitable for the restoration or creation of wetlands. Alternatively, the WRSI map can be used to identify and avoid disturbances to those areas of high potential for sustaining healthy riparian wetlands.

\section{Purpose and Scope}

This report describes the development of a series of estimated flood-inundation maps for the Blue River and selected tributaries at Kansas City, Missouri, and vicinity, identifies where on the Internet the maps are located and can be downloaded; and presents ancillary data (GIS-flood polygons and depth grids). This report also describes and presents a Wetland Restoration Suitability Index for the Blue River and selected tributaries and velocity magnitude data for an 8.2-mile (mi) reach of the Blue River.

The study area includes a 39.7-mile reach of the Blue River from its confluence with the Missouri River, in Kansas City, Mo., upstream to the streamgage near Stanley, Kans. (station number 06893080; fig. 1) and selected tributaries (Brush Creek, Indian Creek, Dyke Branch) between the junction with the Blue River and the Missouri-Kansas State line. The maps were produced for flood levels referenced to stages recorded at the USGS streamgages (table 1) for each mapped reach. For Dyke Branch, a tributary to Indian Creek, only the potential flood-inundation maps that result from backwater effects from Indian Creek were included in the study rather than from local runoff effects. All streamgages referenced in this report are located within Kansas City, Mo., unless otherwise noted and streamgage names are shortened and do not include "Kansas City, Missouri."

The flood-inundation maps cover a range in stages between the NWS Action stage (National Weather Service, 2014a), or approximately bankfull strreamflow, to a stage that approximates or exceeds the stage corresponding to the estimated 0.2-percent annual exceedance probability (AEP) flood (500year recurrence interval flood). The WRSI map covers about the same extent as the flood-inundation map reaches with the area of computation limited to the flood-inundation map reaches and the 0.2 AEP flow extents in the Blue River and its tributaries.

\section{Study Area Description}

The Blue River is located in west central Missouri and east central Kansas in the Central Irregular Plains ecoregion (Omernik, 1987), which can be further divided into the Wooded Osage Plains, Osage Cuestas, Rolling Loess Prairies, and Missouri Alluvial Plain (Omernik, 1987; Chapman and others, 2001; Nigh and Schroeder, 2002). The study basin is characterized by gently rolling to moderately hilly topography 
with about $400 \mathrm{ft}$ of relief. The headwaters originate in Johnson County, Kans., and the stream flows generally northward before entering the Kansas City limits. The drainage area of the main stem Blue River streamgages range from 46 square miles $\left(\mathrm{mi}^{2}\right)$ at the Blue River at Stanley, Kansas, (06893080) to $258 \mathrm{mi}^{2}$ at the Blue River at 12th Street (06893590). Brush Creek (subbasin drainage area of $30 \mathrm{mi}^{2}$ ) and Indian Creek (subbasin drainage area of $75 \mathrm{mi}^{2}$ ) are the two largest tributaries to the Blue River main stem as it flows through Kansas City. Dyke Branch is an ungaged tributary to Indian Creek. The Blue River study reach has an average top-of-bank channel width of about $185 \mathrm{ft}$ and an average channel slope of 4.4 feet per mile ( $\mathrm{ft} / \mathrm{mi})$. The Brush Creek reach is approximately $5.2 \mathrm{mi}$ long and has an average top-of-bank channel width of $117 \mathrm{ft}$ and an average slope of $20.5 \mathrm{ft} / \mathrm{mi}$. The Indian Creek reach is approximately $3.3 \mathrm{mi}$ with an average top-ofbank width of $144 \mathrm{ft}$ and average slope of $15.9 \mathrm{ft} / \mathrm{mi}$.

The Blue River Basin is mostly urbanized downstream from the Blue Ridge Boulevard Extension streamgage (06893150; fig. 1) and primarily grass or forest land upstream from this streamgage (Wilkison and others, 2006). The basin is still under development, as evidenced by an increase of 9.6 percent in housing units from 2000 to 2010 (U.S. Census Bureau, 2010) and new residential development is concentrated in the headwaters of the Blue River. About 50 percent of the land use-land cover in the Blue River Basin is classified in the low- to high-intensity development categories (U.S. Geological Survey, 2006), whereas 78 percent of the Brush Creek Basin is in the low- to high-intensity developed categories, and 69 percent of Indian Creek Basin is in the low- to high-intensity developed category. Commercial and industrial developments are concentrated along the lower reaches of Blue River, Brush Creek, and Indian Creek. The Blue River main stem and tributaries within the study reach have 96 road crossings or other structures (railroad, roadway, and pedestrian bridges, low-head dams/weirs) as of July 2010. Levee protected areas are located near the confluence of the Blue River with the Missouri River and near the confluence of Indian Creek with the Blue River (fig. 1). The leveed areas are included in the U.S. Army Corps of Engineers (USACE) National Levee Database (http://nld.usace.army. mil/egis/f? $p=471: 1:$ ).

\section{Previous Studies}

Flood-inundation maps for the study area previously were developed by Kelly and Rydlund (2006) for the downstream section of the Blue River Basin from the streamgage at 63rd Street (06893530) to the confluence with the Missouri River. Flood-inundation maps also were developed by Kelly and Huizinga (2008) for the upstream section of the Blue River Basin from the streamgage at 63rd Street to the streamgage at Kenneth Road (06893100; fig. 1) that included parts of Indian Creek and Dyke Branch. Flood-inundation maps in the original studies were generated at 2-ft increments and all maps were referenced to a single streamgage, the Blue
River at 63rd Street, Kansas City, Mo. (06893530). The maps generated from these previous studies were developed, in part, by using two-dimensional depth-averaged flow models, and by using water slopes derived from streamgages and Federal Emergency Management Agency (1990) flood-frequency stage-streamflow relations for the remaining main stem and tributaries. Huizinga (2007) updated the two-dimensional model of a 2-mile reach developed by Kelly and Rydlund (2006) in a subsequent study to simulate the potential effects of channel modifications and a proposed grade control structure in the Blue River. Southard (2010) developed regression equations to determine the magnitude and frequency of floods in urban areas in Missouri that included Blue River, Indian Creek, and Brush Creek by using streamgage records in the development of these equations. These regression equations, for which drainage area and percent impervious area are explanatory variables, were used to compute flood streamflows for the 50-, 20-, 10-, 1-, and 0.2-percent AEP flows at the study streamgages (table 2). The computed flood flows and corresponding stages were then used in the determination of the range of simulated flows in the development of floodinundation maps and in the WRSI analyses.

\section{Creation of Flood-Inundation-Map Library}

The USGS has standardized the procedures for creating flood-inundation maps for flood-prone communities (U.S. Geological Survey, 2014b). Tasks specific to development of the flood maps for Kansas City, Mo., were to (1) upgrade five ALERT streamgages on the Blue River (stations 06893195 , 06893510, 06893530, 06893553, and 06893588; table 1) to stage-only streamgages - data that were collected by the City of Kansas City and furnished to the USGS; (2) acquire existing hydraulic models from the USACE (Kellen Huffman, U.S. Army Corps of Engineers, Kansas City District, written commun., 2012 ) used for Blue River channel modification and levee projects, and from the City of Kansas City (James Walton, City of Kansas City, written commun., 2012) for selected Blue River tributaries (Brush Creek, Indian Creek); (3) collect topographic and bathymetric data for selected stream cross sections and geometric data for structures and bridges along the study reach to verify and update existing models and develop additional models to extend coverage; (4) refine estimates of energy-loss factors (roughness coefficients) in the stream channel and flood plain by model calibration; (5) compute water-surface profiles using the U.S. Army Corps of Engineers (USACE) HEC-RAS (U.S. Army Corps of Engineers, 2010) and Depth-Averaged Flow and Sediment Transport Model (FST2DH) (Froehlich, 2003 ) computer programs; (6) produce 345 estimated flood-inundation maps at various stream stages for 15 reaches using the USACE HECGeoRAS computer program (U.S. Army Corps of Engineers, 2009) and a GIS; and (7) prepare maps, both as shapefile 
polygons that depict the areal extent of flood inundation and as depth grids that provide the depth of floodwater for display on a USGS flood-inundation mapping application (http://water. usgs.gov/osw/flood_inundation).

\section{Computation of Water-Surface Profiles}

Water-surface profiles were simulated using five, onedimensional (HEC-RAS, version 4.1; U.S. Army Corps of Engineers, 2010) steady-state models, and two, twodimensional (FST2DH, release 3.3.3; Froehlich, 2003) steady-state models along the 15 mapped reaches. HEC-RAS models were used for development of flood profiles for 9 of the 11 mapped reaches (reaches 1-7, 12-14, fig. 1) along the Blue River (table 3). HEC-RAS models also were used for the development of profiles and flood-inundation maps along Brush Creek (reaches 10-11; fig.1, table 3) and Indian Creek (reach 5; fig. 1, table 3). A HEC-RAS model of the Blue River was obtained from the USACE Kansas City District (Kellen Huffman, U.S. Army Corps of Engineers, written commun., 2012) that began at river mile 0.25 (relative to the confluence of the Blue River and the Missouri River) and extended to river mile 33.527-at the Missouri-Kansas State line (reaches 2-4, 6-7, 12-14). Two additional HEC-RAS models were developed by the USGS for the 6.2 mile reach of the Blue River from the Missouri-Kansas state line to the USGS streamgage near Stanley, Kansas (06893080; mile 33.53 to 39.74; reaches 1-2). Separate HEC-RAS models were provided by the City of Kansas City for the Blue River tributaries of Brush Creek and Indian Creek (James Walton, City of Kansas City, written commun., 2012; reaches 5, 10-11).

The two-dimensional hydraulic model, FST2DH, which is part of the Federal Highway Administration's finite element surface-water modeling system (FESWMS) was used to update models used in previous Blue River flood-inundation studies. FST2DH steady-state simulations were developed and run within the Surface Water Modeling System (SMS, version 11.0; Aquaveo, 2012) graphic-user interface. The FST2DH models were updated and used in this study for consistency with previous studies and to allow for the update and development of simulated two-dimensional velocity maps. The FST2DH models used in previous studies in two, hydraulically-complex Blue River reaches were updated and used in the development of flood-inundation maps for all or part of three map reaches (reaches 7-9; table 3) for an 8.2-mi reach of the Blue River. The two FST2DH models included a 2.48- mi (river mile 10.44 to 12.92 , fig. 2) downstream reach, modified from the two-dimensional model used in Kelly and Rydlund (2006) and Huizinga (2007), and a 5.70-mi, upstream reach (Blue River mile 12.92 to 18.62 , fig. 2), modified from the model developed by Kelly and Huizinga (2008). Updates to the original FST2DH models include channel modifications associated with the USACE Blue River channel modification project (U.S. Army Corps of Engineers, 2012) and represent additional channelization, channel rerouting, bank armoring, and several low-water grade control structures.

\section{Hydrologic Data}

The study-area hydrologic network consists of 15 streamgages (fig. 1; table 1). All of the streamgages were in operation before this project and five of the Kansas City ALERT streamgages were upgraded to USGS furnished record stageonly streamgages during this study. These upgrades allowed the ALERT gage water-level data to be accessible through the USGS National Water Information System (NWIS) database (U.S. Geological Survey, 2014a) and provides for additional quality assurance and quality control of the data by USGS. Water level (stage) is measured continuously (every 15 minutes) at all streamgages, and continuous records of streamflow are currently (2014) computed at 9 of the 15 sites. Eleven of the fifteen sites are NWS-AHPS forecast points (fig. 1) and Kansas City ALERT gages are colocated with USGS streamgages at 10 of the 15 streamgages. Continuous stream stage is measured every 15 minutes, transmitted hourly by a satellite radio in the streamgage, and made available on the Internet through the USGS NWIS. Fourteen of the 15 streamgages also are equipped with recording tipping-bucket rain gages. All watersurface elevations used in this study were referenced to the North American Vertical Datum of 1988 (NAVD 88) and the horizontal reference was the North American Datum of 1983 (NAD 83). Stage data from the streamgages are referenced to a local streamgage datum but can be converted to water-surface elevations referenced to NAVD 88 by adding the streamgage datum elevation (table 1). Stage-streamflow ratings have been developed at 10 of the streamgages and are available through the USGS NWIS Web site (U.S. Geological Survey, 2014a). The current (2014) rating number of the stage-streamflow rating in use at the streamgage and the starting date of the current rating are provided in table 4 . The stage-streamflow rating from streamflow gaging stations (table 4) and documented highwater marks (Donald Wilkison, U.S. Geological Survey, written commun., 2013) from the June 14, 2010, flood were used in the calibration of the HEC-RAS models. High-water marks and streamgage stage readings from the June 14, 2010, flood were used in the calibration/validation of the FST2DH models.

The steady-flow data for the study reaches were obtained from field measurements and stage-streamflow ratings at the Blue River, Brush Creek, and Indian Creek streamgaging stations (table 4). The streamflows used in the model simulations (table 5) were obtained from the stage-streamflow relation at the USGS streamgages (table 4) and correspond with the incremental target stages. Stage-streamflow pairs used for stage-only stations on the Blue River were developed from a calibrated Blue River HEC-RAS model and model inflows were adjusted to attain the 1-ft incremental target stages. The streamgage ratings at nine streamgage stations also were extended using the calibrated HEC-RAS model, if necessary, to obtain stage-streamflow pairs that reached or exceeded the computed 0.2 percent AEP flows. A consideration in delineating model reaches was large tributary junctions. Brush Creek and Indian Creek join the Blue River within the 39.7-mi study reach. The streamgage-derived streamflows were adjusted, 


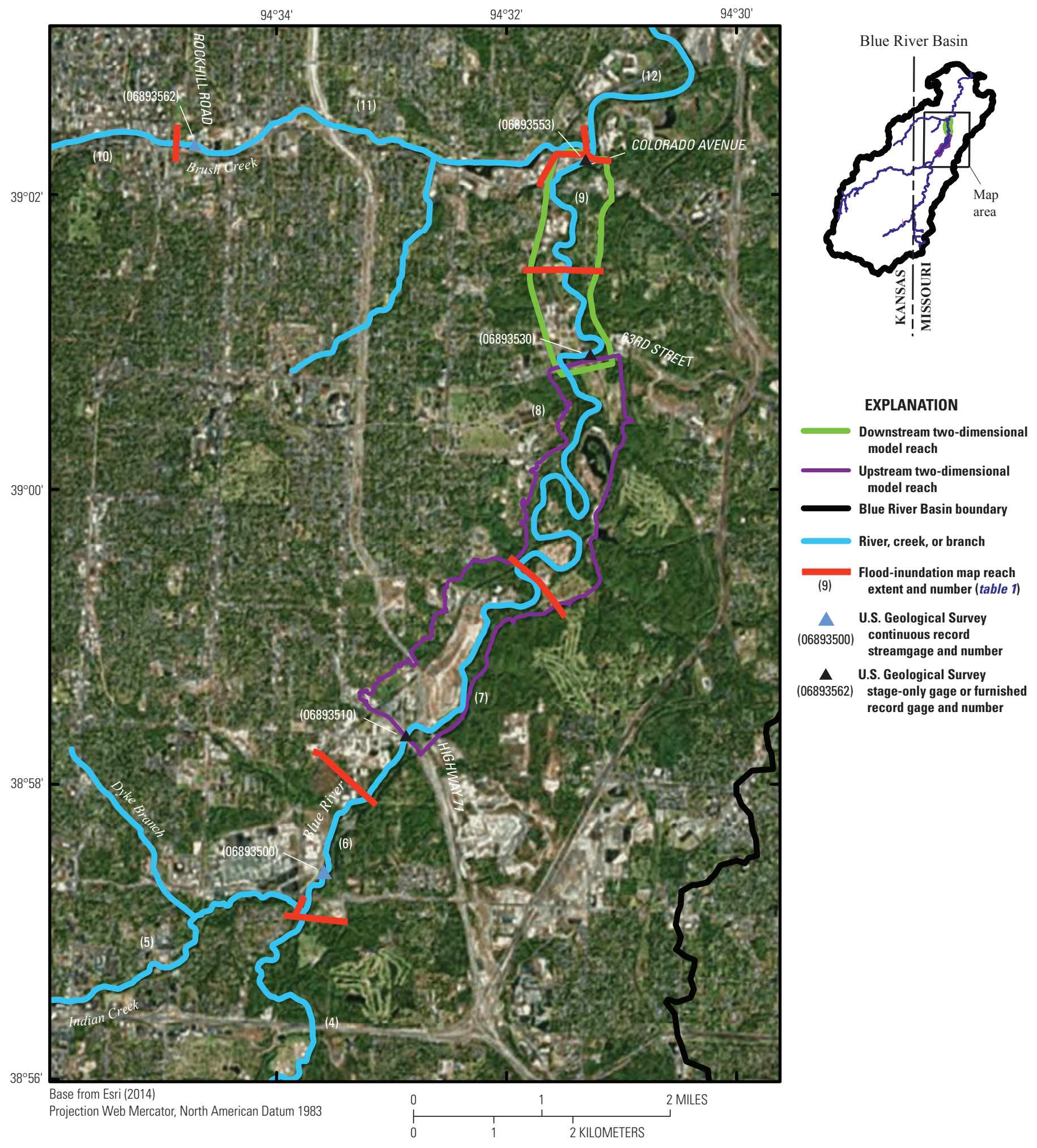

Figure 2. Two-dimensional model reaches of the Blue River, Kansas City, Missouri. 
Table 4. U.S. Geological Survey streamgages and ratings used to provide streamflow and confirm water-surface elevations in the hydraulic models for the Blue River, Brush Creek, and Indian Creek, Kansas City, Missouri, and vicinity.

[Kans.; Kansas; Mo, Missouri]

\begin{tabular}{clcc}
\hline \multicolumn{1}{c}{$\begin{array}{c}\text { Utation } \\
\text { number }\end{array}$} & \multicolumn{1}{c}{$\begin{array}{c}\text { Station } \\
\text { name }\end{array}$} & $\begin{array}{c}\text { Rating } \\
\text { number }\end{array}$ & $\begin{array}{c}\text { Rating } \\
\text { start date }\end{array}$ \\
\hline 06893080 & Blue River near Stanley, Kans. & 17 & $3 / 20 / 2012$ \\
06893100 & Blue River at Kenneth Road, Overland Park, Kans. & 6 & $5 / 22 / 2012$ \\
06893150 & Blue River at Blue Ridge Boulevard Extension, Kansas City, Mo. & 5 & $5 / 1 / 2007$ \\
06893400 & Indian Creek at 103rd Street in Kansas City, Mo. & 3 & $6 / 2 / 2008$ \\
06893590 & Blue River at 12th Street in Kansas City, Mo. & 4 & $10 / 1 / 2006$ \\
06893578 & Blue River at Stadium Drive in Kansas City, Mo. & 4 & $5 / 13 / 2010$ \\
06893562 & Brush Creek at Rockhill Road, Kansas City, Mo. & 6 & $7 / 31 / 2007$ \\
06893557 & Brush Creek at Ward Parkway, Kansas City, Mo. & 7 & $2 / 5 / 2008$ \\
06893500 & Blue River at Kansas City, Mo. & 28 & $11 / 4 / 2010$ \\
06893000 & Missouri River at Kansas City, Mo. & 18 & $4 / 25 / 2007$ \\
\hline
\end{tabular}

as necessary, to account for tributary inflows. These adjustments were estimated from streamflow information obtained from Blue River and tributary streamgages upstream from the tributary confluence.

\section{Topographic and Bathymetric Data}

The terrain model used in the flood-inundation mapping and WRSI analyses was primarily developed from light detection and ranging (lidar) data from Jackson and Cass Counties in Missouri and Johnson County, Kans. All lidar and field survey data meet the horizontal and vertical criteria for the National Standard for Spatial Data Accuracy applicable to flood insurance rate maps (FIRM) (Federal Emergency Management Agency, 2003) as established by the Federal Geographic Data Committee (Federal Geographic Data Committee, 1998). Lidar collection specifications included a vertical root mean square error (RMSE) of less than $0.607 \mathrm{ft}$ at the 95-percent confidence level and a nominal horizontal post spacing of $3.28 \mathrm{ft}$ or less. The $\mathrm{RMSE}_{\mathrm{z}}$ (vertical RMSE) of the elevation data obtained from the topographic mapping data was 0.314 (ft). The nominal horizontal post spacing was 2.46 $\mathrm{ft}$ or less. Lidar data obtained for Jackson and Cass County were collected by Sanborn Mapping Company in April 2006 and post processing was completed in August 2006. Johnson County, Kans., lidar data were collected in December 2011 by the MJ Harden Company; post processing of these data was completed by April 2012. By these criteria, the lidar data support production of 2-ft contours (Dewberry, 2012); the final terrain model, which was resampled to a $3 \mathrm{ft}$ grid-cell size to decrease the GIS processing time, has a vertical accuracy of plus or minus $1 \mathrm{ft}$.
Manmade structures including bridges, culverts, roadway embankments, levees, and weirs, in and along the stream affect, or have the potential to affect, water-surface elevations during floods. Elevations of these features were incorporated into the terrain model of the Blue River Basin used in the processing of flood-inundation maps. New grade-control structures and extensive bank armoring in the 8.2-mi FST2DH modeled reach were surveyed in FebruaryMay 2012; the resulting cross sections provide detailed channel-elevation data below the water surface and were collected using Differential Global Positioning System (DGPS) instrumentation to determine horizontal position and channel-bed elevation.

\section{Hydraulic Structures}

Ninety-six structures, including road, railroad, and pedestrian bridges, and low-head dams and weirs, have the potential to affect water-surface elevations during floods along the study streams. Bridge-geometry data were included in the HECRAS models obtained from the USACE and City of Kansas City. Structure information used in the hydraulic models was current as of June 2010. Selected bridges and structure elevations along the Blue River and Brush Creek and Indian Creek models were field verified in July 2012 by USGS or using as-built construction drawings (James Walton, City of Kansas City, written commun., 2012).

In the HEC-RAS models, the Energy, Momentum, or Yarnell equations (U.S. Army Corps of Engineers, 2010) were computed for low-flow conditions (flows below the low chord of the bridge) through bridges and the final solution used was dependent upon which method computed the greatest energy 
loss through the bridge. During high-flow conditions, pressure solutions were used when the computed energy-grade line exceeded the maximum low-cord bridge elevation at the upstream side of the bridge and weir computations were used when the bridge deck or roadway was overtopped. The type of equation used in the HEC-RAS solution and the stage at which pressure flow or road overflow occurred, if applicable, are provided in table 6. Only in-channel bridge piers (no bridge decks) were included in the two-dimensional model meshes and solutions. Pressure flow information for bridges within the two-dimensional model reaches were, therefore, obtained from the Blue River HEC-RAS models. Bridge piers were, however, included in the two-dimensional models using the pier function and the effects averaged within the mesh element containing the pier, or the pier was simulated using an inactive mesh element dimensioned to represent the bridge pier.

Two leveed areas exist along the Blue River including a 1.1-mile leveed reach near the confluence of the Blue River and the Missouri River and a 0.70 - mile leveed reach near the confluence of Indian Creek and the Blue River (fig. 1). Both levee areas were included in the Blue River main stem HEC-RAS model developed by the USACE (Kellen Huffman, U.S. Army Corps of Engineers, written commun., 2012) and were of a sufficient height to provide flood protection through the range of flows simulated in each of the two respective reaches. The levees also are included in the U.S. Army Corps of Engineers National Levee Database (http://nld.usace.army. mil/egis/f? $p=471: 1:$ ).

\section{Energy-Loss Factors}

Hydraulic analyses require the estimation of energy losses that result from frictional resistance exerted by a channel on flow. These energy losses are quantified by the Manning's roughness coefficient ( $n$ value). Initial (precalibration) $n$ values for energy-loss (friction-loss) calculations were estimated by comparison of field photographs with photographs of channels for which $n$ values have been computed and published in references, such as Barnes (1967), Arcement and Schneider (1989), and Coon (1998). Initial Manning's $n$ values for the two-dimensional models were obtained from previous calibrated versions of the models (Kelly and Rydlund, 2006; Huizinga, 2007; Kelly and Huizinga, 2008).

As part of the calibration process, the initial $n$ values were varied by flow and adjusted until the differences between simulated and observed water-surface elevations at the streamgage and elsewhere along the study reach were minimized. The Blue River flood plain has mixed land uses but is dominated by forested areas upstream from the Blue Ridge Boulevard Extension streamgage (06893150). The channel $n$ values in the channel in this section ranged from 0.04-0.042 and flood-plain values ranged from $0.06-0.15$. Downstream from the Colorado Avenue streamgage (06893553) the Blue River has been channelized and the flood plain is highly urbanized. Channel $n$ values in this section ranged from
0.014-0.041 and flood-plain values ranged from $0.025-0.15$. In the Blue River HEC-RAS models, $n$ values ranged from $0.014-0.046$ for the main channel and $0.025-0.15$ for the flood-plain areas. Brush Creek $n$ values ranged from 0.015-0.04 for the channel, consisting of natural and channelized reaches, and $0.025-0.10$ for flood-plain areas consisting primarily of residential and commercially developed land use. Indian Creek $n$ values ranged from $0.045-0.05$ for the natural channel and $0.06-0.10$ for flood-plain areas consisting primarily of residential land use.

\section{Hydraulic Models}

The hydraulic model analyses for this study used the steady-state flow computation option with one- and twodimensional models. Steady-state flow data consisted of flow regime, boundary conditions, and peak flows that produced water-surface elevations at the streamgage cross section that matched target water-surface elevations. These target elevations coincided with even $1 \mathrm{ft}$ increments of stage that were referenced to the local gage datum; the target elevations ranged from about bankfull to the stage corresponding to the 0.2-percent AEP flow. Subcritical (tranquil) flow regime was assumed for the simulations. For the five one-dimensional models, the downstream boundaries were based on normal depth and estimated friction slope (range of 0.002-0.0006). The downstream boundary conditions for the two-dimensional models were obtained from stage data from the Blue River at 63rd Street streamgage (06893530) and from the calibrated Blue River HEC-RAS model for that reach. The streamflows that were used in the models were discussed in the section, "Hydrologic Data."

The HEC-RAS models were calibrated to the latest stage-streamflow relation in use at the USGS streamgages with measured streamflows (table 4). The two-dimensional models, first calibrated to high-water marks from multiple floods as documented in (Kelly and Rydlund, 2006; Huizinga, 2007; Kelly and Huizinga, 2008 ) were validated using high-water marks from the June 14, 2010, flood and no adjustments were necessary. Model calibration was accomplished by adjusting $n$ values until the results of the hydraulic computations closely agreed with the observed water-surface elevations or stages from the coinciding stage-streamflow rating. Differences between the water-surface elevation from stage-streamflow ratings and simulated water-surface elevations using the multiple HEC-RAS models for the simulated flows at the USGS streamgages were equal to or less than $0.54 \mathrm{ft}$ (table 5). Differences between measured and simulated elevations of high-water marks in the 8.2-mile, twodimensional modeled reach for the flood of June 14, 2010, were less than $0.65 \mathrm{ft}$ (table 7). The results demonstrate that the models are capable of simulating accurate water levels for a wide range of flows in the basin. The accuracy of the simulated water-surface elevations that extend beyond the observed high-water marks or stage-streamflow ratings cannot be quantified. 
Table 7. Comparison of measured and simulated water-surface elevations of the two-dimensional models at selected locations along the Blue River for the flood of June 14, 2010, Kansas City, Missouri.

[NAVD 88, North American Vertical Datum of 1988]

\begin{tabular}{cccc}
\hline $\begin{array}{c}\text { Distance upstream } \\
\text { from mouth of } \\
\text { Blue River } \\
\text { (river miles) }\end{array}$ & $\begin{array}{c}\text { Measured } \\
\text { water-surface } \\
\text { elevation } \\
\text { (feet, NAVD 88) }\end{array}$ & $\begin{array}{c}\text { Simulated } \\
\text { water-surface } \\
\text { elevation } \\
\text { (feet, NAVD 88) }\end{array}$ & $\begin{array}{c}\text { Elevation } \\
\text { difference } \\
\text { (feet) }\end{array}$ \\
\hline 10.83 & 754.23 & 754.10 & 0.13 \\
11.06 & 754.59 & 754.65 & -0.06 \\
11.09 & 754.52 & 753.90 & 0.62 \\
12.87 & 766.60 & 766.43 & 0.17 \\
12.91 (Blue River & & & \\
at 63rd Street & 766.77 & 766.77 & 0.00 \\
streamgage) & & 769.55 & 0.65 \\
13.38 & 770.20 & 774.05 & -0.03 \\
14.70 & 774.02 & & \\
18.56 (Blue River & & 784.51 & 0.04 \\
$\begin{array}{c}\text { at Highway } 71 \\
\text { streamgage) }\end{array}$ & 784.55 & & \\
\hline
\end{tabular}

\section{Development of Water-Surface Profiles}

The calibrated hydraulic models were used to generate water-surface profiles for a range of 14 to 29 stages (table 5) at 1-ft intervals referenced to streamgages in each of the 15 reaches (fig. 1). The water-surface elevations corresponding to the stages were determined from the local datum of the reference streamgage in each reach. Streamflows corresponding to the various stages were obtained from the current stage-streamflow relation for the corresponding reference streamgage (table 4) or from the calibrated Blue River HECRAS models (for stage-only streamgages).

\section{Development of Stream-Velocity Maps}

Stream velocity maps were generated for an 8.2-mi reach of the Blue River using the two-dimensional FST2DH models (both upstream and downstream models, fig. 2). Maps were generated for a range of selected flows and corresponding stages referenced to the Blue River at 63rd Street (06893530) streamgage. Stream velocity point data were generated for flows and stages corresponding to a low range $(41.0 \mathrm{ft}$ and 14,700 cubic feet per second $\left.\left[\mathrm{ft}^{3} / \mathrm{s}\right]\right)$, midrange $(51.0 \mathrm{ft}$ and $\left.36,400 \mathrm{ft}^{3} / \mathrm{s}\right)$, and upper range $\left(59.0 \mathrm{ft}\right.$ and $\left.83,000 \mathrm{ft}^{3} / \mathrm{s}\right)$ in simulated flood conditions. The model output files, including the horizontal position of the point data and corresponding velocity magnitude were imported into ArcGIS software (Esri, 2014) for development of the maps. Velocity magnitude maps were developed and presented corresponding to extents of the FST2DH model rather than a flood-inundation map reach. The two-dimensional modeled reach covers all or part of three flood-inundation map reaches (reaches 7-9, figs. 1-2) referenced to the Blue River at Colorado Avenue (06893553), Blue River at 63rd Street (06893530), and Blue River at Highway 71 (06893510) streamgages.

\section{Constructing Wetland Restoration Suitability Index}

A Wetland Restoration Suitability Index (WRSI) was developed for the Blue River and selected tributaries using a modified version of the WPST developed by the Missouri Department of Natural Resources (Weller, 2008). The GISbased index is determined from a numerical weighting of values from six hydrologic, topographic, and land use-land cover digital feature layers associated with riparian wetlands (table 8, figs. 3-10). All input raster (grid) layers used in the development of the Blue River WRSI had a 3-meter (m) resolution with the exception of the National Land Cover Database (NLCD) data, which had a resolution of $30 \mathrm{~m}$. The final WRSI map was processed with the coarsest input layer resolution of $30 \mathrm{~m}$ and clipped to the 0.2-percent AEP flow extent in the Blue River, Brush Creek and Indian Creek stream corridors for which hydraulic models were developed.

Basin slope (fig. 3) and flow accumulation data layers (fig. 4) were developed from the terrain model used in the study, whereas the flood frequency (50-, 20-, 10-, and 0.2-percent AEP flows) data layer (fig. 5) was developed from the HEC-RAS models and the terrain model. Land cover data (fig. 6) were obtained from the 2011 NLCD (USGS, 2014c) developed by Jin and others (2013). The streams buffer data layer (fig. 7) used to develop buffer distances of $0-100,101-200,201-300$, and greater than $300 \mathrm{~m}$ up to the 0.2-percent AEP flow extent was obtained from the National Hydrography Dataset (U.S. Geological Survey, 2014d). Last, the hydric soils (permanently or seasonally saturated soils) data layer (fig. 8) was obtained from the Soil Survey Geographic (SSURGO) database from the U.S. Department of Agriculture, National Resource Conservation Service (2014). Although the National Wetlands Inventory (NWI; U.S. Fish and Wildlife Service, 2014) data layer was a component of the WPST, it was not included in the Blue River WRSI because imagery used in the development of the NWI for the Kansas City area was from 1983. Substantial urbanization and channel modifications to the lower Blue River have likely altered the distribution of wetlands in parts of the Blue River Basin since that time.

The continuous numerical values for each feature layer were categorized and assigned a discrete scale value of 1 (least suitable) to 10 (most suitable) and each feature was assigned a weighting factor (table 8 ) based on professional judgment similar to methods by Van Lonkhuyzen (2004) and White and Fennessy (2005). The final index was calculated using the categorized layer data and weights and the "Weighted Overlay Table" tool in ArcMap (Esri, 2014) to produce an overall index potential of 1 to 10 . 


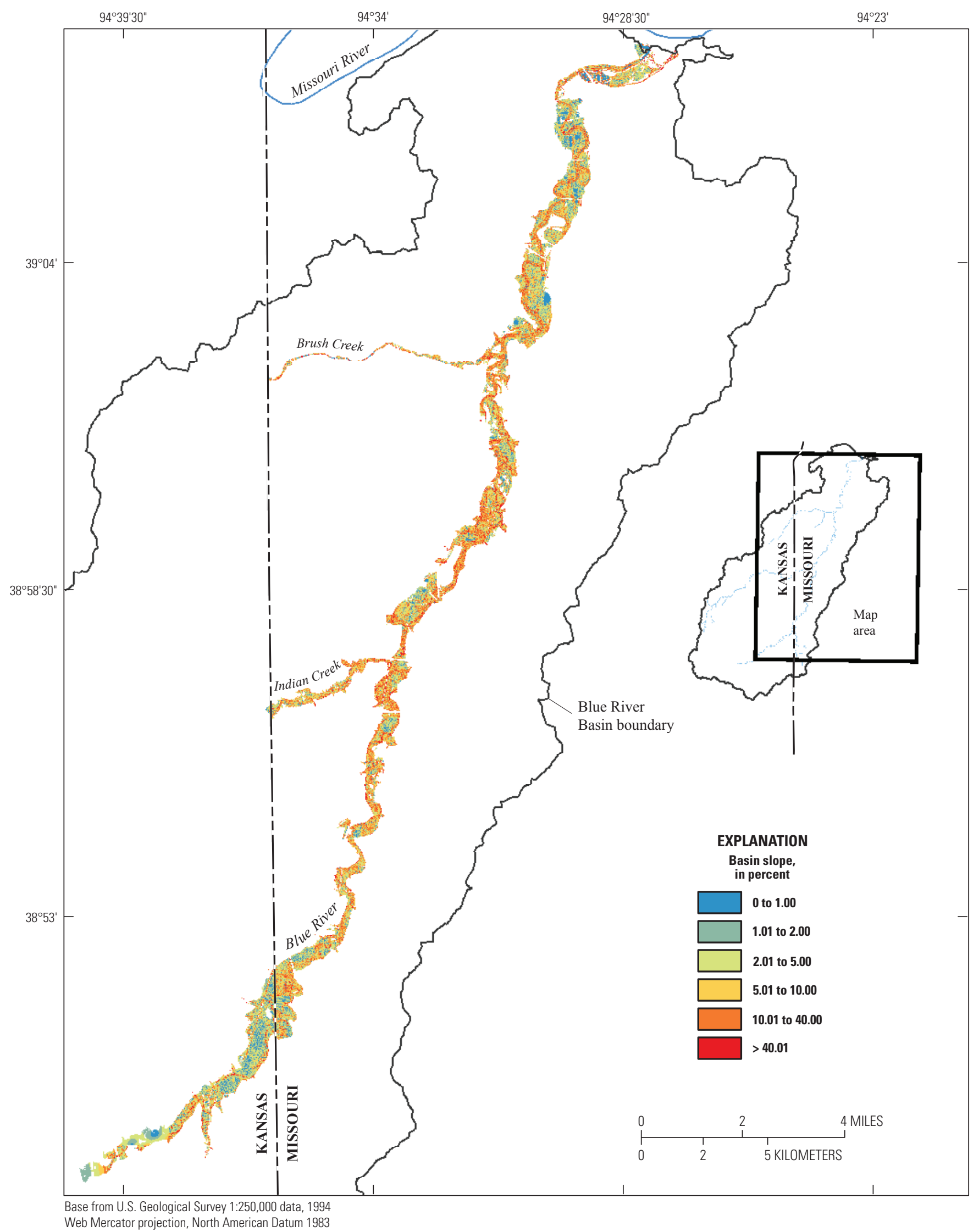

Figure 3. Basin slope data layer used in the development of the Blue River Wetland Restoration Suitability Index, Kansas City, Missouri, and vicinity. 


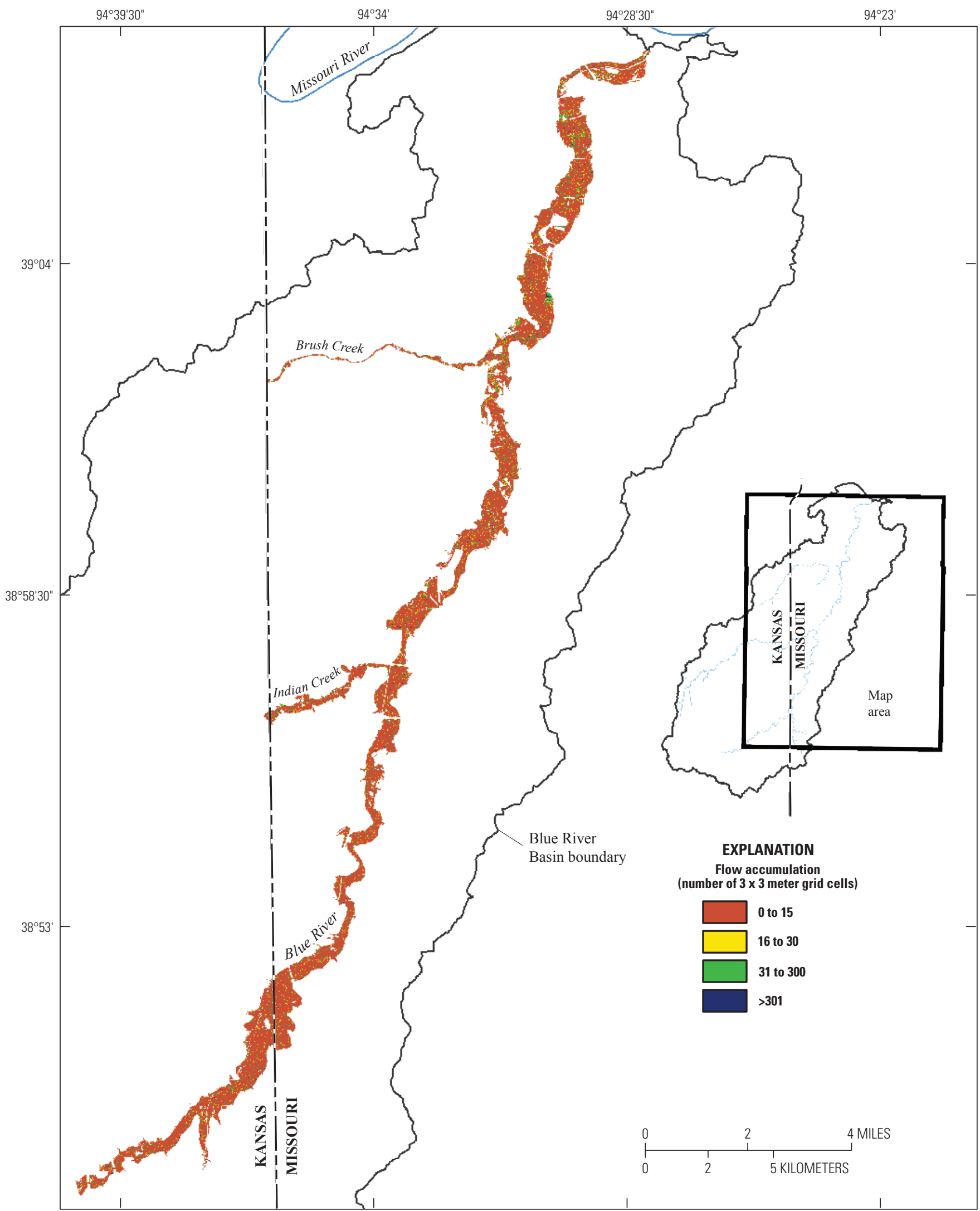

Base from U.S. Geological Survey 1:250,000 data, 1994 Web Mercator projection, North American Datum 1983

Figure 4. Flow-accumulation data layer used in the development of the Blue River Wetland Restoration Suitability Index, Kansas City, Missouri, and vicinity. 


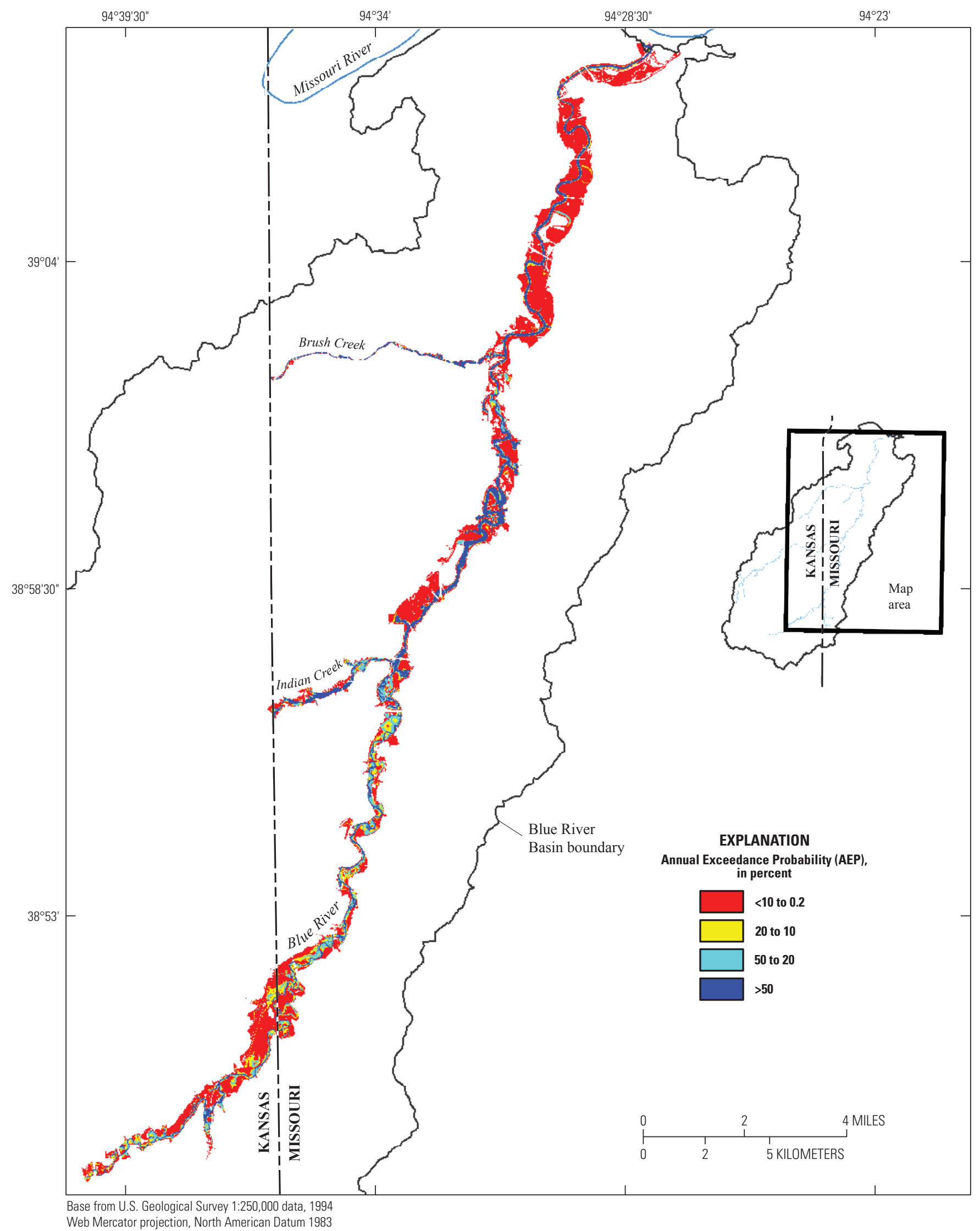

Figure 5. Flood-frequency data layer used in the development of the Blue River Wetland Restoration Suitability Index, Kansas City, Missouri, and vicinity. 


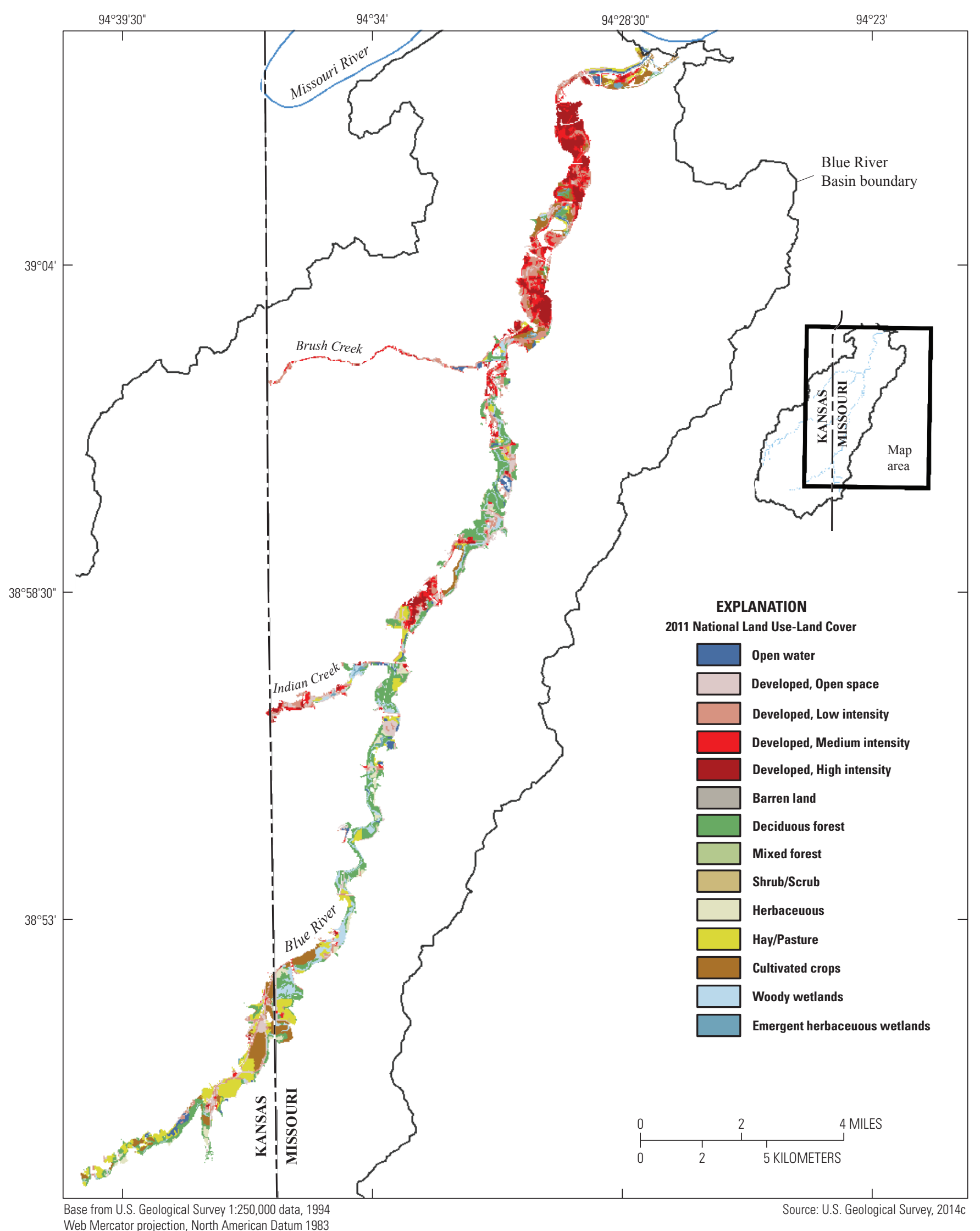

Figure 6. Land-cover data layer used in the development of the Blue River Wetland Restoration Suitability Index, Kansas City, Missouri, and vicinity. 


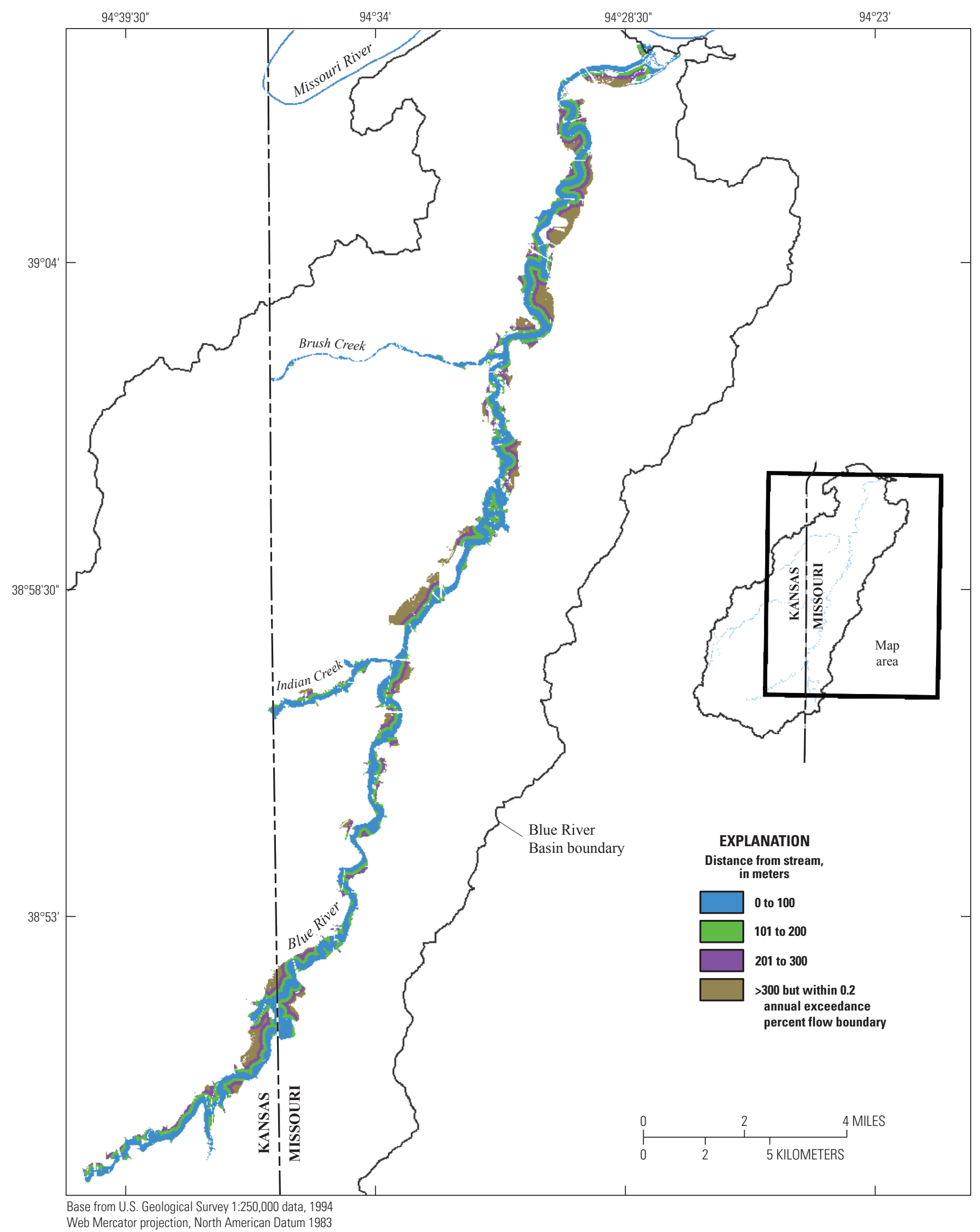

Figure 7. Stream buffer data layer used in the development of the Blue River Wetland Restoration Suitability Index, Kansas City, Missouri, and vicinity. 


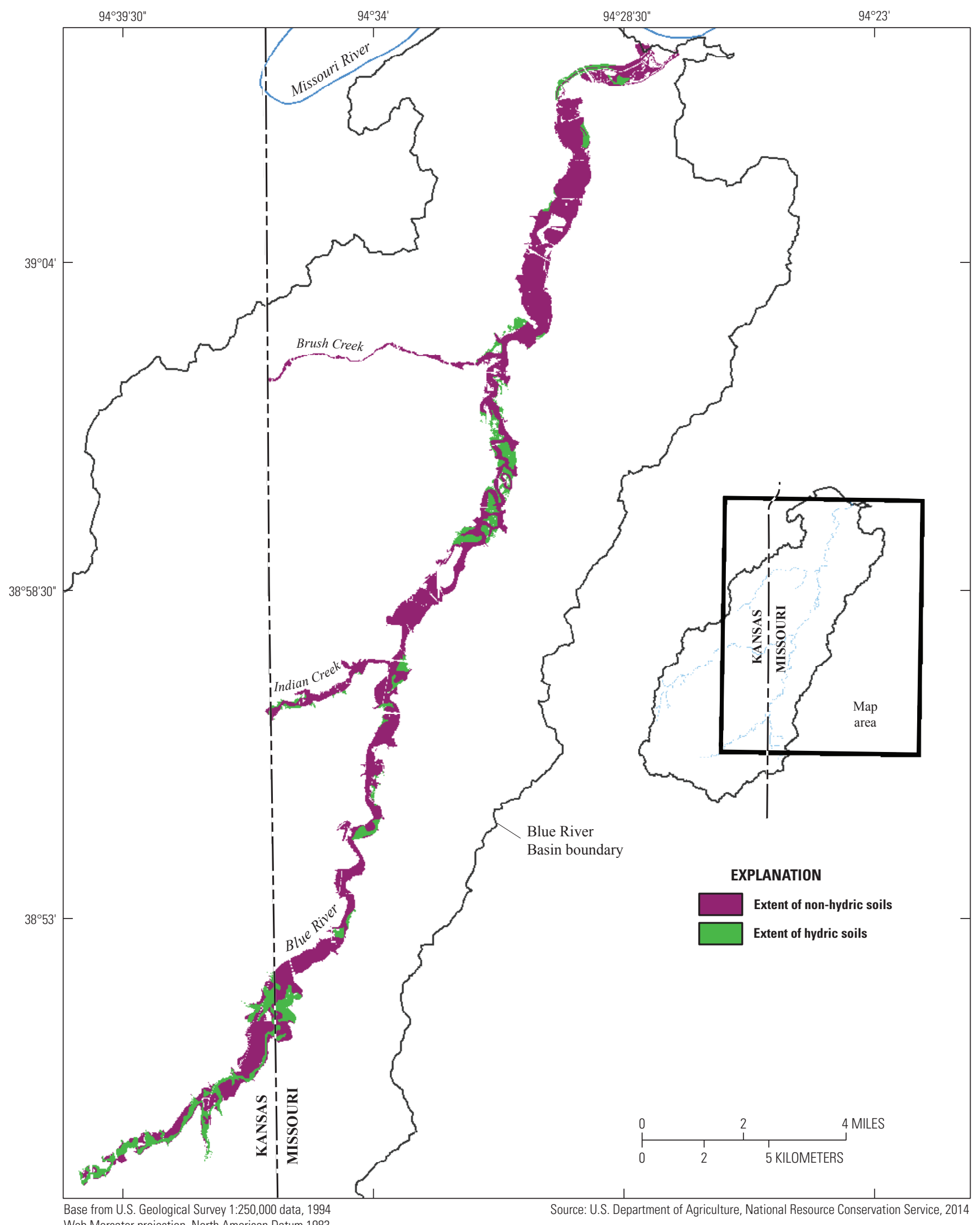

Figure 8. Hydric soils data layer used in the development of the Blue River Wetland Restoration Suitability Index, Kansas City, Missouri, and vicinity. 


\section{Development of Flood-Inundation Maps}

Flood-inundation maps were created for 15 Blue River and tributary reaches referenced to USGS streamgages or furnished stage-record streamgages, 11 of which have been designated as NWS flood-forecast points (as of 2014). The maps were created in a GIS by combining the water-surface profiles and terrain model data. The terrain model data were derived from the same lidar data described previously in the section "Topographic and Bathymetric Data" and, therefore, have an estimated vertical accuracy of $2 \mathrm{ft}$ (that is, plus or minus $1 \mathrm{ft}$ ). Estimated flood-inundation boundaries for each simulated profile in HEC-RAS were developed with HEC-GeoRAS software (U.S. Army Corps of Engineers, 2009), which allows the preparation of geometric data for import into HEC-RAS and processes simulation results exported from HEC-RAS (U.S. Army Corps of Engineers, 2010). Shapefile polygons and depth grids of the inundated areas for each profile were modified, as required, in the ArcMap application of ArcGIS (Esri, 2014) to ensure a hydraulically reasonable transition of the flood boundaries between modeled cross sections.

Any inundated areas that were isolated from the main channel were examined to identify subsurface connections with the main river, such as through culverts under roadways. Where such connections existed, the mapped inundated areas were retained in their respective flood maps; otherwise, the isolated parts of the inundated areas were deleted. The flood-inundation areas were overlain on high-resolution, geo-referenced, aerial photographs of the study area (U.S. Geological Survey, 2014b). Estimates of water depth can be obtained from the depth-grid data that are included with the presentation of the flood maps on an interactive USGS mapping application described in the following section, "Flood-Inundation Map Delivery."

Inundation maps of the estimated effects of backwater from the Missouri River on the Blue River were computed for reach 15 using GIS software. A linear-regression model was developed (fig. 9) between flood stages at the Missouri River at Kansas City, Mo., streamgage (06893000, fig. 1) and the corresponding simulated water surface at the mouth of the Blue River for flows ranging from 50- to 0.2- percent AEP as determined by the U.S. Army Corps of Engineers (2004). The water-surface elevations of the Missouri River at the mouth of the Blue River corresponding to 1-ft stage increments at the Missouri River at Kansas City streamgage were computed using the regression model. A planar surface corresponding to the Missouri River water-surface elevation at the mouth of the Blue River was overlain on the basin terrain model to generate inundation polygons and depth grids for 1-ft stage increments referenced to the Missouri River at Kansas City (06893000) streamgage.

Backwater effects from the Blue River on lower Brush Creek and Indian Creek and backwater effects of Indian Creek on Dyke Branch also were included in the flood-inundation maps. The effects of backwater from the Blue River on Brush Creek were incorporated into the reach maps referenced to the Blue River at Stadium Drive streamgage (06893578), whereas the backwater effects of the Blue River on Indian Creek were included in the reach maps referenced to the Blue River at Kansas City streamgage (06893500). Backwater effects from Indian Creek on Dyke Branch were incorporated into the reach maps referenced to the Indian Creek at 103rd Street streamgage (06893400). The potential for flooding on Dyke Branch resulting from backwater effects from a 0.2-percent

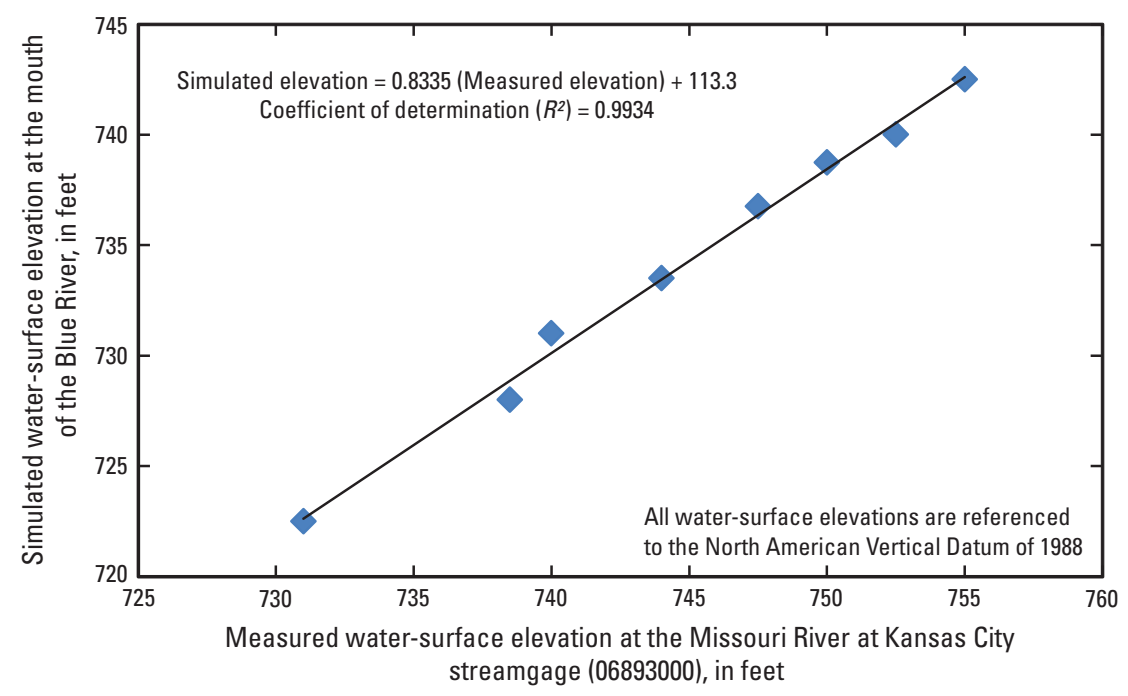

Figure 9. Linear regression model used to compute Missouri River water-surface elevation at the mouth of the Blue River based on stages at the Missouri River at Kansas City, Missouri. (Source of simulated data used in analysis is U.S. Army Corps of Engineers, 2004) 
AEP flow on Indian Creek exceed the potential inundation from a local 0.2-percent AEP flow by as much as $10 \mathrm{ft}$. In each case, the elevation of the water surface profile at the mouth of the these tributaries was used to define the elevation of a planar surface that was overlain on the digital terrain model to define backwater for each 1-ft incremental change in stage at the reference streamgages.

\section{Flood-Inundation Map Delivery}

A Flood-Inundation Mapping Science Web site (http:// water.usgs.gov/osw/flood_inundation/; U.S. Geological Survey, 2014b) has been established to make USGS floodinundation study information available to the public. That site links to a mapping application that presents map libraries and provides detailed information on flood extents and depths for modeled sites. The mapping application enables the production of customized flood-inundation maps from the map library for the 15 study reaches provided in this study. A link on this Web site connects to the USGS NWIS (U.S. Geological Survey, 2014a), which presents the current stage and streamflow at the USGS streamgages to which the inundation maps are referenced. A second link connects to the NWS AHPS site (National Weather Service, 2014b) so that the user can obtain applicable information on forecasted peak stage at forecast points (fig. 1). The estimated flood-inundation maps are displayed in sufficient detail so managers can respond efficiently to flooding and decisions for emergency response can be conducted accordingly. Depending on the flood magnitude, roadways and bridges are shown as shaded (inundated and likely impassable) or not shaded (dry and passable) to facilitate emergency planning and use. A shaded building should not be interpreted to mean that the structure is completely submerged; rather that areas near the building are inundated. In these instances, the water depth (as indicated in the mapping application by holding the cursor over an inundated area) near the building would be an estimate of the water level inside the structure, unless flood-proofing measures had been implemented.

\section{Stream-Velocity Maps}

Two-dimensional stream velocity maps for an $8.2-\mathrm{mi}$ reach of the Blue River were simulated using FST2DH models (fig. 2) for a range of flood conditions referenced to the Blue River at 63rd Street streamgage (06893530). Maps were produced for three stages $(41.0,51.0$, and $59.0 \mathrm{ft}$, table 5$)$ and corresponding flows $\left(14,700,36,400\right.$, and $\left.83,200 \mathrm{ft}^{3} / \mathrm{s}\right)$ representing the range in simulated flood-inundation conditions for both downstream (fig. 10) and upstream model extents (fig. 11). Mean and maximum velocities generally increased with stage and flow in both reaches. Channel velocities generally were greater in the downstream channelized reach (about 5 to $13 \mathrm{ft} / \mathrm{s}$ ) than the unchannelized and more sinuous upstream reach ( 1 to $8 \mathrm{ft} / \mathrm{s}$ ). Maximum velocities generally were near the grade control structure in the downstream reach that constricts flows and marks the transition between natural and channelized stream segments. The channelized reach was designed to convey flows more efficiently through a wider channel, to reduced friction losses, and to increase the gradient, which resulted in greater velocities. Velocities on over bank areas also increased with stage and flow and were similar in both upstream and downstream model reaches.

\section{Disclaimer for Flood-Inundation Maps}

The flood-inundation maps should not be used for navigation, regulatory, permitting, or other legal purposes. The USGS provides these maps "as-is" for a quick reference, emergency planning tool but assumes no legal liability or responsibility resulting from the use of this information.

\section{Uncertainties and Limitations Regarding Use of Flood-Inundation Maps}

Although the flood-inundation maps represent the boundaries of inundated areas with a distinct line, some uncertainty is associated with these maps. The flood boundaries shown were estimated on the basis of water stages and streamflows at selected USGS streamgages. Water-surface elevations along the stream reaches were estimated by steady-state hydraulic modeling, assuming unobstructed flow, and using streamflows and hydrologic conditions anticipated at the USGS streamgages. The hydraulic model reflects the land-cover characteristics and any bridge, dam, levee, or other hydraulic structures existing as of July 2010. Unique meteorological factors (timing and distribution of precipitation) may cause actual streamflows along the modeled reach to vary from those assumed during a flood, which may lead to deviations in the water-surface elevations and inundation boundaries shown. Additional areas may be flooded because of unanticipated conditions such as changes in the streambed elevation or roughness, backwater into large tributaries along a main stem, or backwater from localized debris or ice jams. The accuracy of the floodwater extent portrayed on these maps will vary with the accuracy of the terrain model used to simulate the land surface.

If this series of flood-inundation maps will be used in conjunction with NWS river forecasts, the user should be aware of additional uncertainties that may be inherent or factored into NWS forecast procedures. The NWS uses forecast models to estimate the quantity and timing of water flowing through selected stream reaches in the United States. These forecast models (1) estimate the amount of runoff generated by precipitation and snowmelt, (2) simulate the movement of floodwater as it proceeds downstream, and (3) predict the flow and stage (and water-surface elevation) for the stream at a given location (AHPS forecast point) throughout the forecast period (every 6 hours and 3 to 5 days out in many locations). For more information on AHPS forecasts, refer to http://water. weather.gov/ahps/pcpn_and_river_forecasting.pdf. 


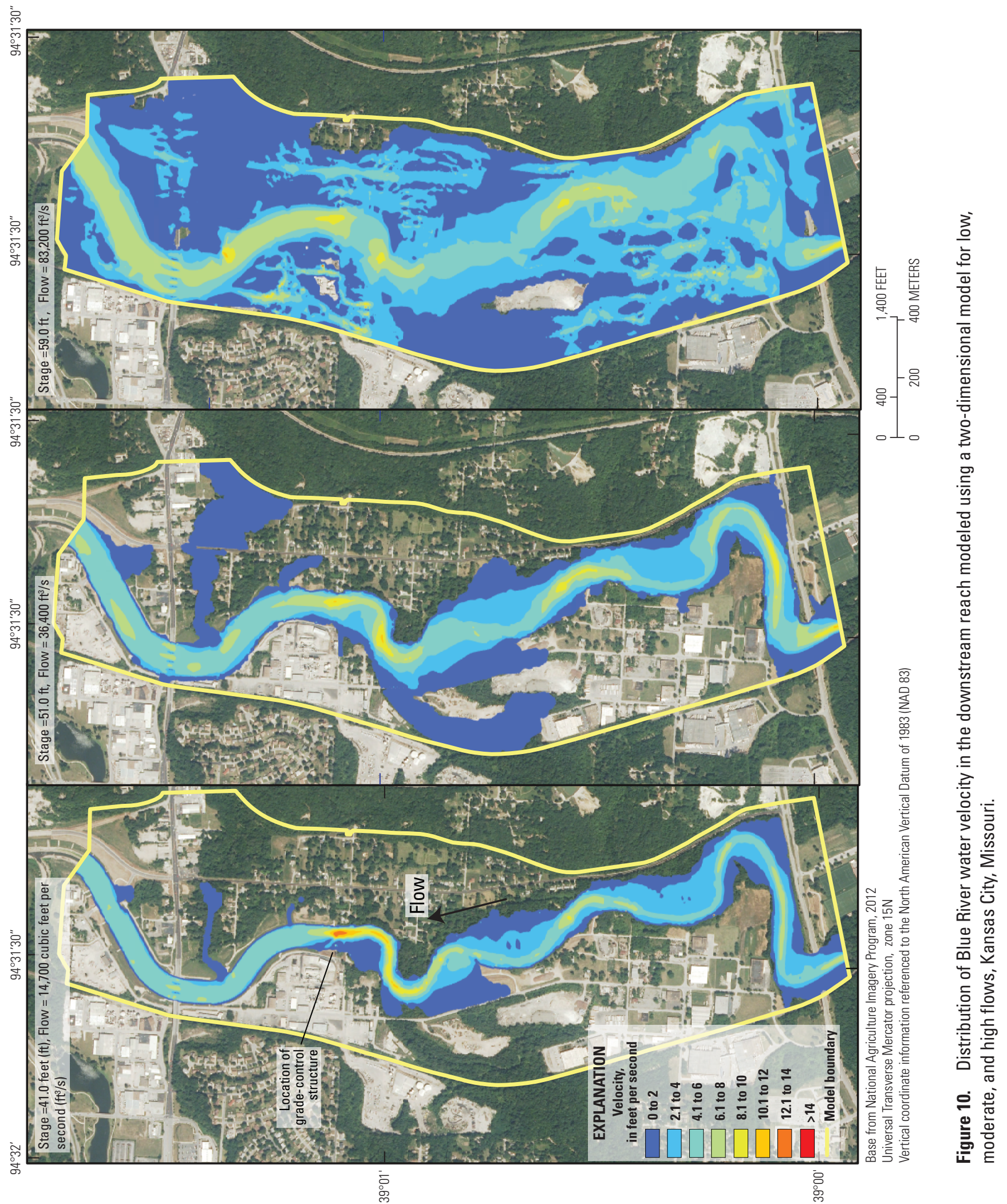



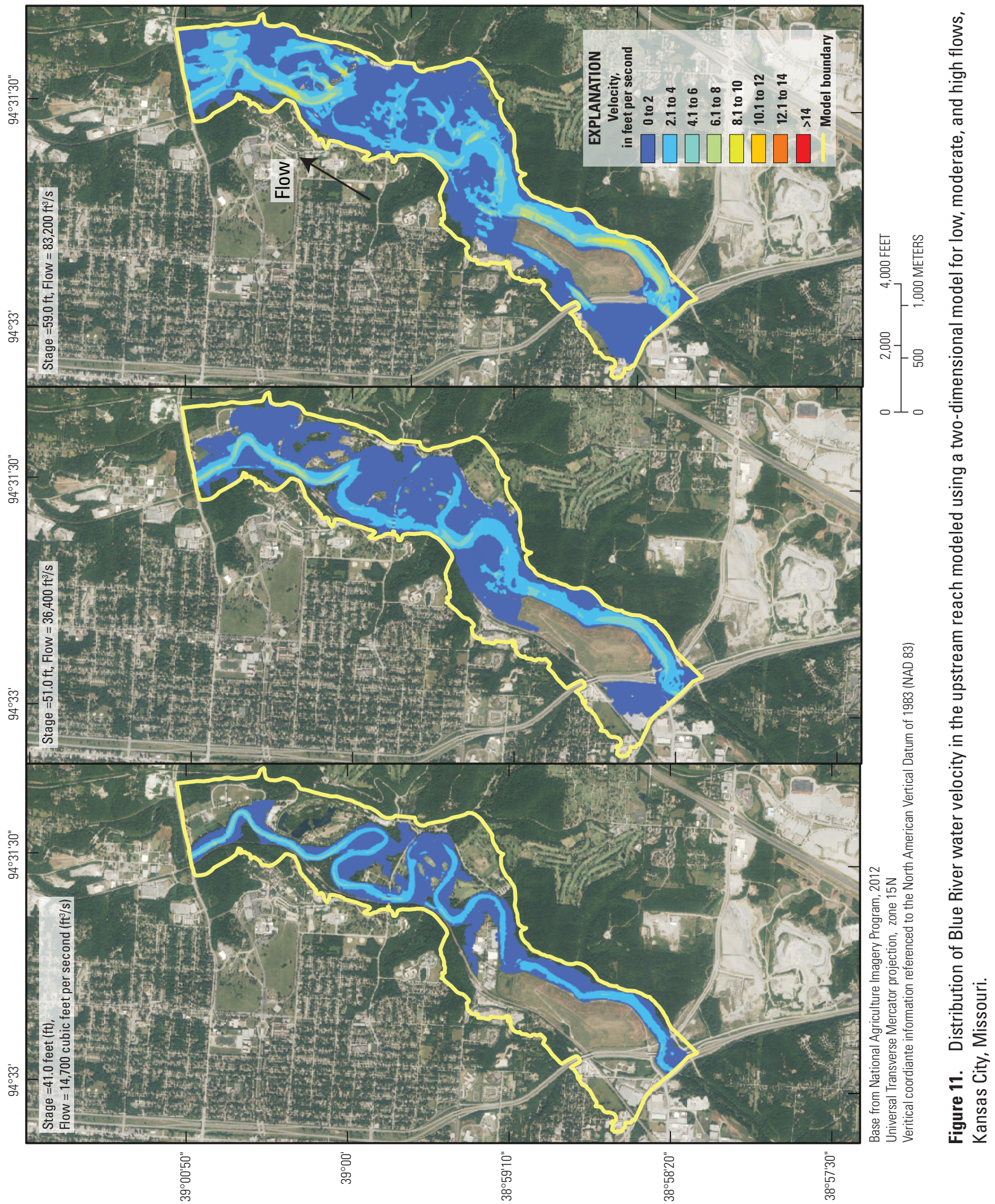


\section{Wetland Restoration Suitability Index}

A Wetland Restoration Suitability Index (WRSI) was computed for the Blue River and selected tributaries using weighted numerical categories associated with six physical and hydrological GIS data layers (table 8, figs. 3-8). The index can be used in possible wetland mitigation efforts, ecological and biological assessments, and protection of areas with high wetland suitability within the selected riparian areas. The resulting WRSI map (fig. 12) shows the spatial distribution of calculated values that ranged from 1 (least suitable for possible wetland mitigation efforts) to 10 (most suitable for possible wetland mitigation efforts). Less than 0.01 percent of the WRSI mapped area attained the maximum potential index value of 10 and the mean index value was 4 . Areas mapped with a WRSI value of 4 represented the largest extent covering about 23 percent of the mapped area. The WRSI values of existing wetlands in the 2011 NLCD range from 3 through 10 , with about 80 percent of the 2011 NLCD wetlands classified with a WRSI of 5 to 10 . A WRSI of 5 to 10 could, therefore, be an indication of areas most likely to support wetlands, regardless of current (2014) land-use conditions. Overall, nearly 40 percent of the flood plain in the analysis area has a WRSI of 5 to 10 and over 80 percent of this area was located upstream from the Blue River at 63rd Street streamgage (06893530, fig. 1), and upstream from the channelized and most developed areas in the basin. The WRSI, which is highly weighted to physical and hydrological conditions necessary to support wetlands, provides a means of identifying areas most suitable for potential restoration or construction of wetlands to limit or reverse losses. Alternatively, those areas with a WRSI of 5 or greater could be identified as areas that are highly susceptible to impairment.

The National Wetlands Inventory data layer (U.S. Fish and Wildlife Service, 2014) based on 1983 imagery for the Kansas City region, indicated that wetlands accounted for approximately 14 percent of the analysis area. The 2011 NLCD layer indicates that approximately 9 percent of the WRSI mapped area is in the wetland land cover classes. The differences in the estimates of wetland area can be used to infer a temporal decline in riparian wetland area of about 36 percent in the Blue River and tributaries from 1983 to 2011 - a possible indication of losses resulting from channel modifications and urbanization along with possible differences in the analysis techniques.

\section{Summary}

Flood-inundation maps were developed in cooperation with the City of Kansas City, Missouri, for a 39.7-mile reach of the Blue River and three tributaries, which included Brush Creek, Indian Creek and Dyke Branch. These maps, in conjunction with the real-time stage data from the USGS streamgages along with National Weather Service flood-stage forecasts, will help to guide the general public in taking individual safety precautions and will provide city officials with a tool to efficiently manage emergency flood operations and flood mitigation efforts.

The maps were developed by using pre-existing and newly developed one-dimensional HEC-RAS and two-dimensional FST2DH hydraulic models to compute water-surface profiles and HEC-GeoRAS and geographic information system programs to delineate estimated flood-inundation areas for selected stream conditions. The hydraulic models were calibrated to the current stage-streamflow relations at the USGS streamgages, and to high-water marks for the flood of June 14, 2010. The models were used to compute water-surface profiles for flood stages at 1-ft intervals referenced to the streamgage datum and ranging from the National Weather Service Action stage (about bankfull flow) to that which exceeds the stage of the estimated 0.2-percent annual exceedance probability. The simulated water-surface profiles were then combined with a geographic information system digital elevation model derived from light detection and ranging data to delineate estimated flood-inundation areas as shapefile polygons and depth grids for each water-surface profile. The flood maps are available through a mapping application that can be accessed on the USGS Flood-Inundation Mapping Science Web site (http:// water.usgs.gov/osw/flood_inundation).

Two-dimensional finite-element hydraulic models were used to generate maps of stream channel velocities in addition to flood-inundation extents for an 8.2-mile reach of the Blue River. Stream velocity maps were generated for low, moderate, and high floods. Model results indicate maximum main channel velocities of more than 14 feet per second (ft/s), but velocities generally ranged from 5 to $13 \mathrm{ft} / \mathrm{s}$ in channelized reaches and 1 to $8 \mathrm{ft} / \mathrm{s}$ in unchannelized reaches with floodplain velocities generally less than $2 \mathrm{ft} / \mathrm{s}$.

A Wetland Restoration Suitability Index (WRSI) also was developed for the same reaches as the flood-inundation maps for the Blue River and selected tributaries using six digital feature layers including basin slope, flow accumulation, flood frequency, land use, stream buffer, and hydric soils. The feature layers were categorized and weighted to produce an index map showing areas ranging from least (1) to most (10) suitable for wetland restoration. Index values varied from 1 to 10 with a mean of 4. Areas with a WRSI of 5 to 10 represented about 40 percent of the mapped riparian area and were the most closely associated with the identified wetland land-cover classes in the 2011 National Land Cover Database. The WRSI provides a tool to identify areas most suitable for potential wetland restoration or construction and to identify and limit impairment of areas most suitable for supporting high-quality riparian wetlands. 


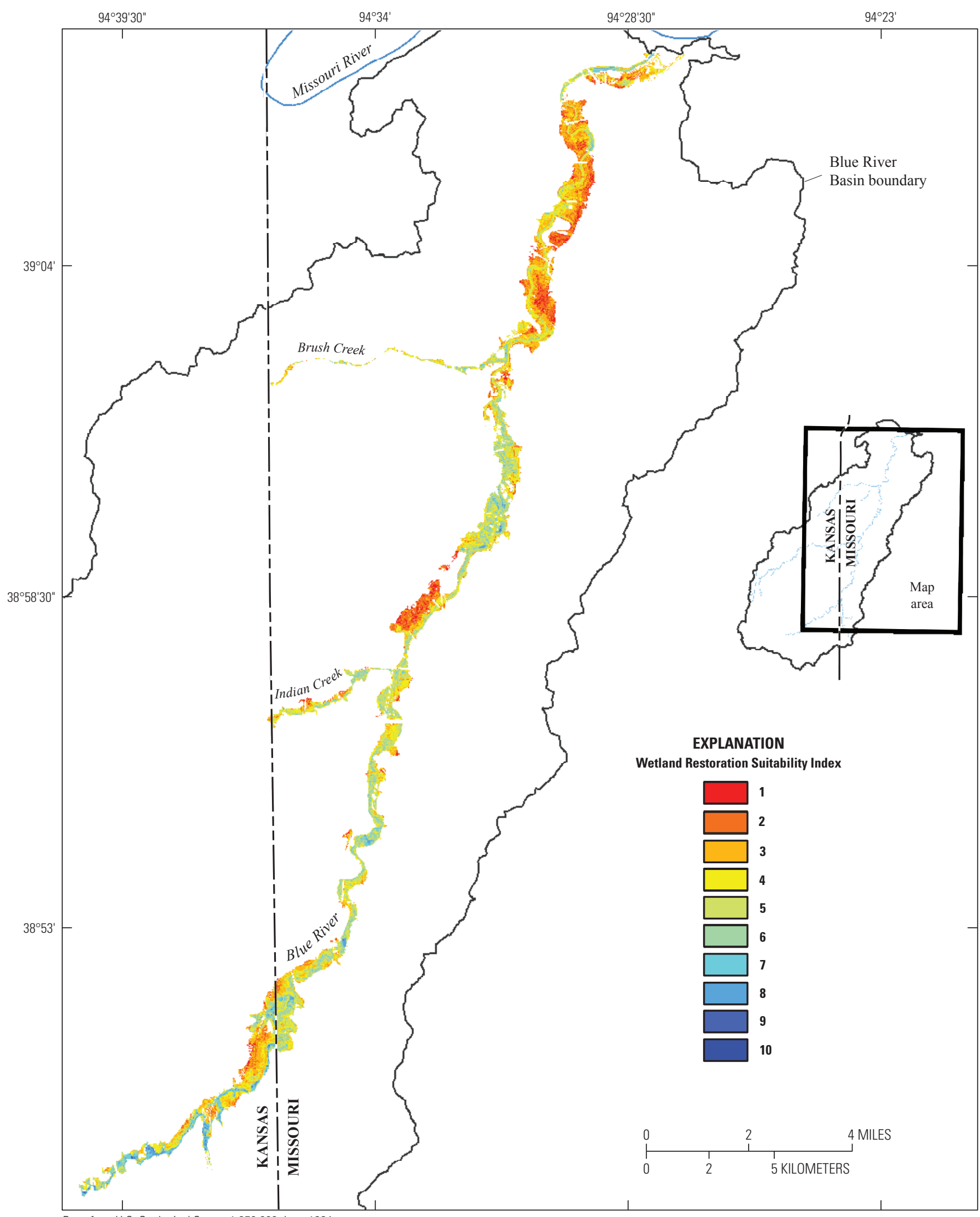

Base from U.S. Geological Survey 1:250,000 data, 1994 Web Mercator projection, North American Datum 1983

Figure 12. Wetland Restoration Suitability Index map for the riparian areas of the Blue River and selected tributaries, Kansas City, Missouri, and vicinity. 


\section{References Cited}

Aquaveo, 2012, Surface-Water Modeling System (SMS): South Jordan, Utah, accessed March 2012 at https://www. aquaveo.com/software/sms-surface-water-modeling-systemintroduction.

Arcement, G.J., and Schneider, V.R., 1989, Roughness coefficients for natural channels and flood plains: U.S. Geological Survey Water-Supply Paper 2339, 38 p.

Barnes, H.H., 1967, Roughness characteristics of natural channels: U.S. Geological Survey Water-Supply Paper 1849, $213 \mathrm{p}$.

Brush Creek Coordinating Committee, 2013, The Brush Creek watershed history of flooding: accessed May 7, 2013, at http://brushcreekwatershed.com/wp/?p=143.

Chapman, S.S., Omernik, J.M., Freeouf, J.A., Huggins, D.G., McCauley, J.R., Freeman, C.C., Steinauer, G., Angelo, R.T., and Schlepp, R.L., 2001, Ecoregions of Iowa and Missouri: Reston, Va., U.S. Geological Survey (map scale 1:1,950,000), accessed October 11, 2013 at http://www.epa. gov/wed/pages/ecoregions/moia_eco.htm.

Coon, W.F., 1998, Estimation of roughness coefficients for natural stream channels with vegetated banks: U.S. Geological Survey Water-Supply Paper 2441, 133p.

Dahl, T.E., 1990, Wetland losses in the United States 1780s to 1980s: Washington, D.C., U.S. Department of the Interior, Fish and Wildlife Service, 13 p.

Dewberry, 2012, [revised], National Enhanced Elevation Assessment: Fairfax, Va., Dewberry, 84 p., accessed July 2013, at $h t t p: / / w w w . d e w b e r r y . c o m / f i l e s / p d f / N E E A_{-}$ Final\%20Report_Revised\%203.29.12.pdf.

Ehrenfeld, J.G., 2004, The expression of multiple functions in urban forested wetlands: Wetlands, v. 24, no. 4, p. 719-733.

Esri, [2014], ArcGIS-Mapping and analysis for understanding our world, version 10.2: Esri Web accessed June 17, 2014, at http://www.esri.com/software/arcgis/.

Federal Emergency Management Agency, 1990, Flood insurance study, City of Kansas City, Missouri, Clay, Platte, and Jackson counties: Federal Emergency Management Agency, 84 p.

Federal Emergency Management Agency, 2003, Guidelines and specifications for flood hazard mapping partners: Federal Emergency Management Agency, 1,779 p., accessed April 4, 2013 at http://www.fema.gov/media-library/assets/documents/13948.

Federal Geographic Data Committee, 1998, Geospatial positioning accuracy standards, Part 3-National standard for spatial data accuracy: Federal Geographic Data Committee, Subcommittee for Base Cartographic Data, Report FGDCSTD-007.3-1998, 28 p.
Froehlich, D.C., 2003, User's Manual for FESWMS FST2DH-Two-dimensional depth-averaged flow and sediment transport model: Federal Highway Administration Report No. FHWA-RD-03-053, [variously paged].

Hauth, L.D. and W.J. Carswell, Jr., 1981, Floods in Kansas City, Missouri and Kansas, September 12-13, 1977: U.S. Geological Survey Professional Paper P1169, 47 p.

Huizinga, R.J., 2007, Two-dimensional hydrodynamic modeling and analysis of the proposed channel modifications and grade control structure on the Blue River near Byram's Ford Industrial Park, Kansas City, Missouri: U.S. Geological Survey Scientific Investigations Report 2007-5098, 45 p.

Jin, S., Yang, L., Danielson, P., Homer, C., Fry, J., and Xian, G., 2013, A comprehensive change detection method for updating the National Land Cover Database to circa 2011: Remote Sensing of Environment, v. 132: 159-175.

Kelly, B.P., and Rydlund, P.H., Jr., 2006, Estimated floodinundation mapping for the lower Blue River in Kansas City, Missouri, 2003-05: U.S. Geological Survey Scientific Investigations Report 2006-5089, 27 p.

Kelly, B.P., and Huizinga, R.J., 2008, Estimated flood-inundation mapping for the Upper Blue River, Indian Creek, and Dyke Branch in Kansas City, Missouri, 2006-08: U.S. Geological Survey Scientific Investigations Report 2008-5068, 34 p., plus appendixes.

National Oceanic and Atmospheric Administration, National Weather Service, 2014a, National Weather Service Glossary: accessed June 20, 2014, at http://w1.weather.gov/ glossary/index.php? word=action+stage.

National Oceanic and Atmospheric Administration, National Weather Service, 2014b, Advanced Hydrologic Prediction Service: accessed June 20, 2014, at http://water.weather. gov/ahps/forecasts.php.

Nigh, T.A., and Schroeder, W.A., 2002, Atlas of Missouri ecoregions: Missouri Department of Conservation, $212 \mathrm{p}$.

Omernik, J.M., 1987, Ecoregions of the conterminous United States: Association of American Geographers, v. 77, p. 118-125.

Southard, R.E., 2010, Estimating the magnitude and frequency of floods in urban basins in Missouri: U.S. Geological Survey Scientific Investigations Report 2010-5073, 27 p.

U.S. Army Corps of Engineers, 1967, Flood plain information, Blue River within Kansas City, Missouri: U.S. Army Corps of Engineers, Kansas City District, 31 p.

U.S. Army Corps of Engineers, 2004, Upper Mississippi River system flow frequency study, Appendix E of Missouri River hydrology and hydraulic analysis: Vicksburg, Miss., U.S. Army Corps of Engineers, Kansas City District, $111 \mathrm{p}$. 
U.S. Army Corps of Engineers, Hydrologic Engineering Center, 2009, HEC-GeoRAS, GIS Tools for Support of HEC-RAS using ArcGIS, User's Manual, version 4.2,: Vicksburg, Miss., U.S. Army Corps of Engineers, [variously paged].

U.S. Army Corps of Engineers, Hydrologic Engineering Center, 2010, HEC-RAS River Analysis System, Hydraulic Reference Manual, version 4.1: U.S. Army Corps of Engineers, [variously paged].

U.S. Army Corps of Engineers, 2012, Blue River channel modification: accessed February 11: 2012 at http://www.nwk.usace.army.mil/Missions/ CivilWorks/CivilWorksProgramsandProjects/ BlueRiverChannelModification.aspx.

U.S. Census Bureau, 2010, State population datasetsPopulation, population change and estimated components of population change: accessed July 2013 at $h t t p: / / w w w$. census.gov/2010census/popmap/ipmtext.php? $f=29$.

U.S. Department of Agriculture, Farm Service Agency, 2012, Imagery Programs, NAIP Imagery: U.S. Department of Agriculture, Farm Service Agency Web page, accessed May 13, 2014 at $h t t p: / / w w w . f s a . u s d a . g o v / F S A / a p f o a p p ?$ area $=h o$ me\&subject $=$ prog\&topic $=$ nai .

U.S. Department of Agriculture, National Resource Conservation Service, 2014, Description of SSURGO database: U.S. Department of Agriculture, accessed June 3, 2014 at http://www.nrcs.usda.gov/wps/portal/nrcs/detail/soils/ survey/?cid=nrcs142p2_053627.

U.S. Fish and Wildlife Service, 2014, National Wetlands Inventory: accessed April 2014 at $h t t p: / / w w w . f w s . g o v /$ wetlands/.

U.S. Geological Survey, 2006, National Land Cover Database (NLCD): Multi-Resolution Land Characteristics Consortium, accessed June 3, 2013 at http://www.mrlc.gov/ mrlc $2 k \_n l c d . a s p$.

U.S. Geological Survey, 2014a, USGS surface-water data for the Nation: U.S. Geological Survey, National Water Information System, accessed June 2014, at http://waterdata. usgs.gov/nwis/sw.

U.S. Geological Survey, 2014b, USGS Flood Inundation Mapping Science: U.S. Geological Survey, accessed June 2014, at http://water.usgs.gov/osw/flood_inundation.

U.S. Geological Survey, 2014c, National Land Cover Database (NLCD), 2011-Multi-Resolution Land Characteristics Consortium: U.S. Geological Survey, accessed June 27: 2014 at http://www.mrlc.gov/mrlc2k_nlcd.asp.

U.S. Geological Survey, 2014d, National Hydrography Dataset: U.S. Geological Survey, accessed June 2014, at http:// nhd.usgs.gov/data.html.
Van Lonkhuyzen, R.A., Lagory, K.E. and Kuiper, J.A., 2004, Modeling the suitability of potential wetland mitigation sites with a geographic information system: Environmental Management, v. 33, no.3, p.368-375.

Weller, M.S., 2008, Headwater wetlands in agricultural areas in Missouri: Missouri Department of Natural Resources, 34 p., accessed August 2013 at http://www.dnr.mo.gov/env/ wrc/docs/WPSTGrantFinalReportforWeb.pdf.

White, D., and Fennessy, S., 2005, Modeling the suitability of wetland restoration potential at the watershed scale: Ecological Engineering, v. 24, p. 359-377.

Wilkison, D.H., Armstrong, D.J., Norman, R.D, Poulton, B.C., Furlong, E.T., and Zaugg, S.D, 2006, Water quality in the Blue River Basin, Kansas City metropolitan area, Missouri and Kansas, July 1988 to October 2004: U.S. Geological Survey Scientific Investigations Report 2006-5147, 170 p.

Publishing support provided by: Rolla Publishing Service Center

For more information concerning this publication, contact: Director, USGS Missouri Water Science Center 1400 Independence Road

Rolla, M0 65401

(573) 308-3667

Or visit the Missouri Water Science Center Web site at: http://mo.water.usgs.gov/ 




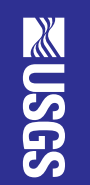

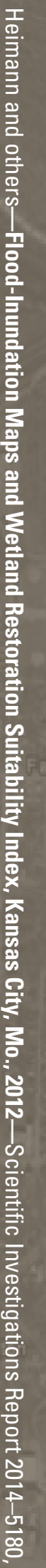

